\title{
Equity/Equality, Diversity, and Inclusion (EDI) in Universities: The Case of Disabled People
}

\author{
Gregor Wolbring * ${ }^{(\mathbb{D}}$ and Aspen Lillywhite \\ Community Rehabilitation and Disability Studies, Department of Community Health Sciences, \\ Cumming School of Medicine, University of Calgary, Calgary, AB T2N4N1, Canada; \\ aspen.lillywhite1@ucalgary.ca \\ * Correspondence: gwolbrin@ucalgary.ca
}

Citation: Wolbring, G.; Lillywhite, A. Equity/Equality, Diversity, and Inclusion (EDI) in Universities: The Case of Disabled People. Societies 2021, 11, 49. https://doi.org/ $10.3390 /$ soc11020049

Academic Editor: Sandro Serpa

Received: 23 April 2021

Accepted: 12 May 2021

Published: 18 May 2021

Publisher's Note: MDPI stays neutral with regard to jurisdictional claims in published maps and institutional affiliations.

Copyright: (c) 2021 by the authors. Licensee MDPI, Basel, Switzerland. This article is an open access article distributed under the terms and conditions of the Creative Commons Attribution (CC BY) license (https:/ / creativecommons.org/licenses/by/ $4.0 /)$.
Abstract: The origin of equity/equality, diversity, and inclusion (EDI) initiatives at universities are rooted in the 2005 Athena SWAN (Scientific Women's Academic Network) charter from Advance HE in the UK, which has the purpose of initiating actions that generate gender equality in UK universities. Since then, Advance HE also set up a "race charter" to deal with equality issues that are experienced by ethnic staff and students within higher education. Today "equality, diversity and inclusion" and "equity, diversity and inclusion" (from now on both called EDI) are used as phrases by universities in many countries to highlight ongoing efforts to rectify the problems that are linked to EDI of students, non-academic staff, and academic staff, whereby the focus broadened from gender to include other underrepresented groups, including disabled students, disabled non-academic staff, and disabled academic staff. How EDI efforts are operationalized impacts the success and utility of EDI efforts for disabled students, non-academic staff, and academic staff, and impacts the social situation of disabled people in general. As such, we analysed in a first step using a scoping review approach, how disabled students, non-academic staff, and academic staff are engaged with in the EDI focused academic literature. Little engagement (16 sources, some only abstracts, some abstracts, and full text) with disabled students, non-academic staff, and academic staff was found. This bodes ill for the utility of existing EDI efforts for disabled students, non-academic staff, and academic staff, but also suggests an opening for many fields to critically analyse EDI efforts in relation to disabled students, non-academic staff, and academic staff, the intersectionality of disabled people with other EDI groups and the impact of the EDI efforts on the social situation of disabled people beyond educational settings. The problematic findings are discussed through the lens of ability studies and EDI premises, as evident in EDI policy documents, EDI academic, and non-academic literature covering non-disability groups, and policy documents, such as the 2017 "UNESCO Recommendation on Science and Scientific Researchers" and the 1999 "UNESCO World Conference on Sciences" recommendations that engage with the situation of researchers and research in universities.

Keywords: disabled students; disabled academics; students with disabilities; academics with disabilities; academic disabled staff; non-academic disabled staff; ableism; disablism; "equity, diversity and inclusion"; "equality, diversity and inclusion"

\section{Introduction}

Athena SWAN (Scientific Women's Academic Network) is a charter that originated from the UK in 2005. The purpose of the Athena SWAN program is to obtain gender equality in higher education and research [1]. The Athena SWAN program has 10 principles that higher education institutions are committing themselves to adopt "within their policies, practice, action plans and culture" [1]. One of these principles is to consider the intersectionality of gender with other factors [1]. The Athena SWAN charter expanded over time to, for example, include transgender and Advance HE recently produced a race equality charter that "aims to improve the representation, progression and success of minority ethnic staff 
and students within higher education" [2] and "provides a framework through which institutions work to identify and self-reflect on institutional and cultural barriers standing in the way of Black, Asian and Minority Ethnic staff and students" [2]. Advance HE also has content on their webpage indicating the problematic situation of disabled people in higher education [3]. The Athena SWAN framework is applied outside the UK [1] in modified ways in many universities using the phrases "equity, diversity and inclusion" [4-13] or "equality, diversity and inclusion" [12,14-16] (EDI) or both phrases [17,18]. Universities in many countries have strategic EDI plans [19-23]. Canada has an EDI Charter [24] that is endorsed by Canadian universities. According to the Canadian EDI charter, the aim of EDI is to increase "research excellence, innovation and creativity within the post-secondary sector across all disciplines" [24] to strengthen "the research community, the quality, relevance and impact of research and the opportunities for the full pool of potential participants" [24], and the Canadian EDI Charter recognized that "an in-depth and intersectional understanding of inequity, discrimination and exclusion is needed to achieve cultural change" [24]. Disabled students, non-academic staff, and academic staff ${ }^{1}$ fall under EDI. At the same time, many academic studies and international policy documents acknowledge that disabled students, non-academic staff, and academic staff encounter severe problems in post-secondary education [23,25-33], which, in turn, pose challenges for implementing EDI in relation to disabled students, non-academic staff, and academic staff. Furthermore, how EDI is operationalized impacts not only disabled students, non-academic staff and academic staff in their post-secondary settings, but it also impacts how academia engages with the many social problems disabled people face, for example, evident in the UN Convention on the Rights of Persons with Disabilities [34], and whether academia fixes the recognized problem that data are missing on the social situation of disabled people [35-39]. As such, in a first step using a scoping review approach, we analysed how disabled students, non-academic staff, and academic staff are engaged with in the EDI focused academic literature to identify the extent of research that has been conducted on EDI in relation to disabled people in universities to understand the topic better. The research question is: to what extent is EDI engaged with in relation to disabled students, non-academic staff, and academic staff in universities in the academic literature. To answer the research question, we looked at the frequency of how often the academic literature engaged with EDI in universities in relation to disabled students, disabled non-academic staff, disabled academic, and in relation to disability and the words used to describe disabled students, academic, and non-academic staff in the university in relation to EDI. Furthermore, we looked at themes that appeared in the coverage of disabled students, disabled non-academic staff, and disabled academic in relation to EDI. The findings are discussed through the lens of ability studies and the EDI academic and non-academic literature in existence in relation to non-disability groups, EDI premises, as evident in EDI policy documents and policy documents, such as the 2017 "UNESCO Recommendation on Science and Scientific Researchers" [40] and the 1999 "UNESCO World Conference on Sciences" $[29,30]$ recommendations that engage with the situation of researchers in universities.

\subsection{EDI}

EDI becomes an ever-important part within many universities, including Canadian universities [4-11]. The origin of the EDI initiatives is rooted in the 2005 Athena SWAN (Scientific Women's Academic Network) charter from "Advance HE" in the UK, which has the purpose of initiating actions that generate gender equality in higher education and research [1]. Given the success of the Athena SWAN charter, Advance HE recently introduced a "Race Equality Charter" in the UK "to improve the representation, progression and success of minority ethnic staff and students within higher education" [2]. The Athena SWAN charter framework has been established in modified forms in other places, such as

1 We acknowledge that there is an ongoing discussion regarding whether one should use people first language (people with disabilities) instead of using identity first language (disabled people). We identify with disabled people instead of people first language and, as such, use the disabled people version in our own writing. 
Australia (Science in Australia Gender Equity, SAGE-Athena SWAN); the USA (See change with STEMM Equity Achievement, SEA-Change and NSF ADVANCE); and, Canada (DIMENSIONS: Equity, diversity and inclusion) [41]. Canadian EDI efforts in universities are guided by the "Canadian Multiculturalism Act (1988), the Charter of Rights and Freedoms (1982), the Employment Equity Act (1986, revised in 1996) and the Canadian Human Rights Act (1977)" [19] (p. 43). The concept of employment equity was introduced in Canada by the 1984 Royal Commission on Equality in Employment [42], which focused on four groups: "women, persons with disabilities, Indigenous peoples and members of visible (or racialized) minorities" [43] (p. 6). The webpage of universities Canada suggest that EDI enriches the universities and that the aim of members of universities Canada is to develop an EDI action plan; to report the progress; to provide equity of access and opportunity by identifying barriers; to make visible and promote best practices of EDI; and, to be guided by evidence [44].

The Canadian Tri-agency funding agencies, the Canadian Institutes of Health Research, the Natural Sciences and Engineering Research Council, and the Social Sciences and Humanities Research Council in their focus on EDI define equity as "the removal of systemic barriers and biases enabling all individuals to have equal opportunity to access and benefit from the program", diversity as "differences in race, colour, place of origin, religion, immigrant and newcomer status, ethnic origin, ability, sex, sexual orientation, gender identity, gender expression and age", and inclusion as "the practice of ensuring that all individuals are valued and respected for their contributions and equally supported" [45]. They also provide definitions for microaggression "brief and common verbal, behavioural or institutional actions that play into stereotypes or discrimination against a group of people, often from underrepresented groups", tokenism and unconscious bias [45]. According to their webpage, they are committed to "supporting equitable access to funding opportunities for all researchers and trainees; promoting the integration of equity, diversity, and inclusion-related considerations in research design and practices; increasing equitable and inclusive participation in the research system, including on research teams and collecting the data and conducting the analyses needed to include equity, diversity and inclusion considerations in decision-making" [45]. Dimensions is a program through which Canadian Tri-agency funders want to achieve EDI and "drive deeper cultural change within the research ecosystem" [46]. The Dimension Charter asks for equitable, inclusive, and unbiased systems and practices and the generation of qualitative and quantitative data to "inform a comprehensive, in-depth, intersectional understanding of the contexts, manifestations and experiences that result from inequities, underrepresentation and exclusion among all post-secondary community members" [47]. The Dimension Charter sees EDI as essential for research and EDI is seen as a shared responsibility of everyone. Furthermore, the Dimension Charter acknowledges that "institutional and individual safety, trust, belonging, privacy and power differentials must be recognized and pro-actively addressed" [47]. The Canada Research Chairs EDI endeavour [32] focuses on "excellence in research and research training for the benefit of Canadians" [32] and sees EDI in the research arena as essential in generating impactful research and responding to global challenges [32].

EDI endeavours align with the 2017 UNESCO Recommendation on Science and Scientific Researchers [40] which stated

"Ill. The initial education and training of scientific researchers section 13 To assist the emergence of scientific researchers of this high calibre, Member States should take measures to: (a) ensure that, without discrimination on the basis of race, colour, descent, sex, gender, sexual orientation, age, native language, religion, political or other opinion, national origin, ethnic origin, social origin, economic or social condition of birth, or disability, all citizens enjoy equal opportunities for the initial education and training needed to qualify for research and development careers, as well as ensuring that all citizens who succeed in so qualifying enjoy equal access to available employment in scientific research; (b) abolish inequalities of opportunities; (c) in order to remediate past inequalities and patterns of 
exclusion, actively encourage women and persons of other under-represented groups to consider careers in sciences and endeavour to eliminate biases against women and persons of other under-represented groups in work environments and appraisal" [40] (p. 120)

Within the EDI academic literature not focusing on disabled people, various EDI problems have been identified and solutions proposed; for example, the lack of race and gender diversity in STEM education [48-53] was highlighted, whereby the solutions suggested that one has to deal with this absence starting in early childhood [48]. The following 10 rules for building an antiracist lab were suggested: lead informed discussions, address racism, publish, and write grants with people targeted by racism, mentor, amplify the voices experiencing racism, support them in their organizing efforts, recruit them as students and non-academic and academic staff, flexible research agenda, advocate for racially diverse leadership in science, hold the powerful accountable, and do not expect gratitude [50]. Other problems that were identified and solutions proposed were: address leaky pipeline, go beyond academia, make women visible [51], move toward high-context approaches to learning [52], institutional culture changes in academia [53], fight implicit biases and microaggressions [54,55], become literate, acknowledge ones privilege, speak out as a privileged one [55], change problematic representation in textbooks [56], increased research in EDI because the existing gender equity initiatives do not lead to intended levels of career advancements in the field [57], and increased intersectionality and moving away from the "superwomen" [57] (p. 1779). Problems also include the ability to identify correctly and deal with "implicit bias", "status leveling", "color-blind racial attitudes", "tokenism", and "failure to differentiate" [58] (p. 286), and developing career development programs as a possible solution [59]. In one article it was noted: "the level of inclusion that racially minoritized academics in our study felt within their workplaces depended upon their experiences with (1) acceptance (e.g., through hiring, promotion, and tenure); (2) visibility (e.g., in terms of perceived power in informal and formal work interactions);

(3) support (e.g., via collegial and administrative encouragement, assistance, collaboration, and resource support); and, (4) mentoring (e.g., in terms of providing and seeking mentor experiences)" [60] (p. 1).

\subsection{Identity and Situation of Disabled People in Universities in General and Mentioning within} Science Policy Frameworks

Within Canadian universities, the definition of disabled people follows the wordings of the employment equity act of the Government of Canada

"persons with disabilities means persons who have long-term or recurring physical, mental, sensory, psychiatric or learning impairment and who (a) consider themselves to be disadvantaged in employment by reason of that impairment, or (b) believe that a employer or potential employer is likely to consider them to be disadvantaged in employment by reason of that impairment and includes persons whose functional limitations owing to their impairment have been accommodated in their current job or workplace" [61] a definition also used by Statistic Canada [62]

The examples for a 'disability' given are:

"acquired brain injury, ADHD, autism spectrum disorder, chronic health disability (e.g., Crohn's disease, hemophilia, epilepsy, asthma, diabetes, HIV / AIDS, cancer, pain etc.), coordination or dexterity disability (e.g., arthritis, cerebral palsy, cystic fibrosis, multiple sclerosis), deaf, deafened, hard of hearing, learning disability, mental health disability (e.g., schizophrenia, chronic depression, anxiety disorder, bipolar disorder, etc.), mobility disability (e.g., amputations; paraplegia; reliance on a walker, scooter or mobility aid due to disability), speech impairment (e.g., aphasia, stuttering, cluttering, etc.), vision loss or impairment, legally blind (not correctable by glasses or contact lenses)" [62] 
Universities in other countries have similar definitions for disability. For UK universities, see [63]; their disability definition aligns with the definition, as outlined in Equality Act of 2010 [64] referenced in [65]. For New Zealand, see, for example, the university of Auckland [66], and, for Australia, for example, Curtin university [67] states.

The definition of disability is very broad and includes physical, psychological, sensory, intellectual disabilities, and medical conditions. A disability might be something that affects or limits your movements, your senses, your communication abilities, or your learning abilities. It may or may not be visible, and it may be permanent or temporary. It may be something you were born with, or it may have appeared later in life or resulted from something that has happened to you. Some people have more than one disability" Common disabilities and medical conditions seen at university are: attention deficit hyperactivity disorder (ADHD), autism spectrum disorder, mental health problems, such as depression, anxiety, bipolar affective disorder, and schizophrenia, specific learning disabilities, such as dyslexia and dysgraphia, and medical problems, such as chronic fatigue syndrome, epilepsy, and diabetes. Temporary disabilities, such as fractures and injuries, as well as vision and hearing impairments [67].

University policies and people's views of disabled people within universities often align themselves with a biomedical understanding of disability $[23,68,69]$, whereby not being able to have a positive self-identity is flagged as a problem [70,71].

Many academic studies covering many countries argue that disabled students, nonacademic staff, and academic staff, in general, encounter severe problems in post-secondary education and academic employment $[22,25-28,71-83]$ and experience numerous barriers $[25,84-86]$. These barriers include a lack of financial support [87,88], difficulty seeking accommodations (e.g., being apprehensive about disclosure, lacking self-advocacy skills) $[86,89]$, and outright discrimination, such as lack of access to and within built structures $[87,88]$, lack of awareness of faculty and peers $[87,89,90]$, lack of agreement on the concept of "inclusive pedagogy" [91], and strain on time resources [88].

Many problems also exist for disabled graduate researchers and faculty in many countries [22,23,27,72,79,82,83,92-99]. For example, according to Statistics Canada, 35\% of disabled university professors, instructors, teachers, or researchers "experienced unfair treatment or discrimination in the past 12 months" and $47 \%$ saw themselves "subjected to at least one type of harassment in the past 12 months" [100]. With that, the numbers for disabled university professors, instructors, teachers, or researchers are the highest of all groups recorded [100]. The respective numbers for, for example "no self reported disability" were $15.4 \%$ and $26.0 \%$; "female gender", $23.0 \%$ and $34.0 \%$; "visible minorities", $23.0 \%$ and $28.0 \%$; and, "indigenous identity", $30.0 \%$ and $37.0 \%$. Harassment is also seen as a problem in other places outside Canada [101-103].

Disabled people encountering problems in university settings is recognized not only in academic literature, but also international science policy documents, such as the documents of the 1999 UNESCO World Conference on Sciences [29,30]. Within its documents of the conferences focusing on the situation within sciences under point 25 , it is stated "that there are barriers which have precluded the full participation of other groups, of both sexes, including disabled people, indigenous peoples and ethnic minorities, hereafter referred to as "disadvantaged groups..." [29] (also see point 42 [29]). The conference documents suggest many action items to be implemented in relation to disabled people and other disadvantaged groups under point 17, point 79 and point 81 [30]. Furthermore, under point 91, the following action items are listed "Special efforts also need to be made to ensure the full participation of disadvantaged groups in science and technology, such efforts to include: removing barriers in the education system; removing barriers in the research system; raising awareness of the contribution of these groups to science and technology in order to overcome existing stereotypes; undertaking research, supported by the collection of data, documenting constraints; monitoring implementation and documenting best practices; ensuring representation in policy-making bodies and forums" [30]. As such, these documents $[29,30]$ highlight some outcomes that are needed from EDI actions. 


\section{Materials and Methods}

\subsection{Theoretical Frameworks and Lenses}

Ability studies [104] and the linkage to role and identity theories guide the interpretation of what this study found in relation to EDI and disabled people. Ability studies is a lens that investigates the cultural reality of ability expectations (nice to have) and ableism (essential to have), how ability expectations and ableism sentiments come to pass, and the consequences of any given ability expectation and ableism [104,105]. It draws from the discourse around ableism (for a bibliography, see [106]). Ableism was coined by the disabled people's rights movement in the 1960's and 1970's [107] to question irrelevant normative body ability expectations and the "ability privileges (i.e., ability to work, to gain education, to be part of society, to have a positive identity, to be seen as a citizen)" [108] (p. 119) that come with them. Ableism and ability expectations were also established to question disablism, the ability expectation, and ableism oppression, the negative treatment, of the ones judged as impaired as "ability-wanted" by applying irrelevant body ability expectations [108,109]. It is for example, stated: "A pernicious impact of ableism is its tendency to take-for-granted ability as a legitimate criterion for negative differential treatment, thereby making disability discrimination difficult to challenge for people with disabilities" [110] (p. 76). Ableism is also discussed in relation to post-secondary institutions [72,73]. Ability expectations and ableism play themselves out on the intersections of different forms of humans, humans-post/transhumans; humanscyborg humans; Humans-Animals; Humans-Nature; and, humans/animals/nature-non sentient/sentient machine [104,105], some of which already play themselves out in various aspects of academia, and some that will reshape academia in the future. Ability expectations and ableism can be used to disable or enable [111]. The term EDI itself signifies three ability expectations (equity, diversity, and inclusion) that are seen by people that are involved in the EDI discourse as positive abilities to experience. However, if not done right, the same potentially positive ability expectations could become disabling and not enabling for disabled people and other EDI groups. How one engages with ability expectations and ableism within EDI influences the EDI ability expectation of being able to lead to deep cultural change [24]. EDI narratives exhibit many ability expectations and ableism needed to experience the ability to experience EDI, not only in relation to disabled people, but, in general, such as EDI has the ability to "strengthen the research community, the quality, relevance and impact of research and the opportunities for the full pool of potential participants" [24]. Ability studies have many concepts that are important for the EDI discourse, such as ability inequity, which is defined as (a) an unjust or unfair distribution of access to and protection from abilities generated through human interventions and (b) an unjust or unfair judgment of abilities intrinsic to biological structures, such as the human body [112]. Other important ability concepts include ability identity security (to be able to have a positive identity based on one's abilities) [112] and ability security (to have a decent life with ones set of abilities) [112].

There are many social factors that define the self, according to identity theory [113]. Identities are social products, contain self-meaning, include that one's response is similar to the response by others, reflexive and a "source of motivation for action particularly actions that result in the social confirmation of the identity" [114] (p. 242). Much has been written regarding the social factors that define disabled people, how one is identified, and how one self-identifies [115-117]. The expectation of having certain abilities is one social factor that influences one's self-identity and the identity others bestow on oneself, in general, including disabled people [105,112]. As such, how disabled people and others are defined within the EDI discourse has consequences for how disabled students, nonacademic staff, and academic staff define themselves and are defined by others. One can have many different identities, whereby different identities have varied impact on oneself [113]. Therein, how EDI identifies disabled people and others and whether one experiences ability identity security within EDI discourses impacts the intersectionality between disabled people and others. The perception of 'self' is influenced by the role that 
one occupies in the social world [113], the perception attached to oneself influences the role one seeks to have [118-121], and the role others think one could fill [122]. As such, the implementations of EDI raise the question of what roles are disabled people and other EDI groups are to play in the university and outside of universities?

\subsection{Study Design}

Scoping studies are useful in identifying the extent of research that has been conducted on a given topic $[123,124]$ and the current understanding of a given topic. In this scoping study, the focus is on the extent of research that has been conducted (a) on EDI frameworks such as Athena SWAN, SEA change, SAGE-Athena SWAN, NSF ADVANCE and DIMENSIONS: Equity, diversity and inclusion and disabled people at universities and (b) the EDI phrases "Equality, diversity and inclusion" or "Equity, diversity and inclusion" in relation to disabled people at universities. Furthermore, it was investigated what the academic literature that uses the three words "equality", "diversity" and "inclusion" or the three words "equity", "diversity", and "inclusion", but not the phrases, say, in relation to disabled people at universities. A modified version of the stages for a scoping review outlined by [125] is employed, namely: identifying the research questions of the review, identifying applicable databases to search, generating inclusion/exclusion criteria, recording the descriptive quantitative results, selecting literature based on descriptive quantitative results for content coding of qualitative data, and reporting the findings of qualitative analysis.

\subsection{Identification of Research Question and Inclusion and Exclusion Criteria}

The following research question was investigated: to what extent is EDI engaged with in the academic literature in relation to disabled people (students, academic staff and non-academic staff) at universities. To answer this question, we looked at the frequency of how often the academic literature engaged with EDI in universities in relation to disabled students, disabled non-academic staff, disabled academic, and in relation to disability and the words used to describe disabled students, academic and non-academic staff in the university in relation to EDI. Furthermore, we looked at themes that appeared in the coverage of disabled students, disabled non-academic staff, and disabled academic in relation to EDI. Regarding inclusion criteria, for the initial selection of sources for content analysis, all data found with the search strategies (Table 1) have to indicate an engagement with disabled people at universities in relation to (a) EDI frameworks, such as Athena SWAN, SEA change, SAGE-Athena SWAN, NSF ADVANCE or DIMENSIONS: Equity, diversity, and inclusion (strategy 1-2), or (b) the EDI phrases "Equality, diversity and inclusion" or "Equity, diversity and inclusion"(strategies 3), or (c) all terms "equality", "diversity", and "inclusion" or "equity", "diversity", and "inclusion" (strategy 4), even if not used as phrase as under strategy 3 in order to be analysed. The research strategy also covers the Athena SWAN and SAGE-Athena SWAN framework although their focus is on gender. However, studies could exist that investigated the Athena SWAN and SAGEAthena SWAN programs through the lens of disability studies, given that they have such an impact on higher education institutions that sign up for them. Such investigations could have analysed the impact of institutions signing up for them on disabled people at universities and the potential for setting up similar initiatives that cover disabled people at university. 
Table 1. Search Strategy used.

\begin{tabular}{|c|c|c|}
\hline Strategy & Sources Used & First Search \\
\hline Strategy 1 & Scopus/EBSCO-Host & ABS ("Athena SWAN") \\
\hline Strategy $2 \mathrm{a}$ & Scopus/EBSCO-Host & $\begin{array}{c}\text { Full text ("Athena SWAN") AND ("disab" OR "autism" OR "deaf" } \\
\text { OR "ASD" OR "ADHD" OR "impair") }\end{array}$ \\
\hline Strategy $2 b$ & Scopus/EBSCO-Host & Full Text ("See change with STEMM Equity Achievement") \\
\hline Strategy 2c & Scopus/EBSCO-Host & Full Text "Dimensions: equity, diversity and inclusion" \\
\hline Strategy $2 \mathrm{~d}$ & Scopus/EBSCO-Host & Full Text ("Science in Australia Gender Equity") \\
\hline Strategy $2 \mathrm{e}$ & Scopus/EBSCO-Host & Full Text ("NSF ADVANCE") \\
\hline Strategy 3a & Scopus/EBSCO-Host & ABS ("equity, diversity and inclusion") \\
\hline Strategy $3 b$ & Scopus/EBSCO-Host & ABS ("equality, diversity and inclusion") \\
\hline Strategy $4 \mathrm{a}$ & Scopus/EBSCO-Host & ABS ("equity" AND “diversity" AND “inclusion") \\
\hline Strategy $4 b$ & Scopus/EBSCO-Host & ABS ("equality" AND “diversity" AND “inclusion") \\
\hline
\end{tabular}

Regarding the exclusion criteria, all data found through the search strategies not covering the content mentioned under inclusion criteria are excluded from the content analysis. Furthermore, the academic source must be peer reviewed articles or conference papers, or editorials, or reviews or book chapters, and the language has to be in English.

\subsection{Data Sources and Data Collection}

The academic databases EBSCO-HOST (an umbrella database that includes over 70 other databases itself) and Scopus (that incorporates the full Medline database collection) were searched on 18 October 2020 (for strategy 1, 3a, and 4a) and 1 February 2021 (for strategy $2 a-e, 3 b$, and $4 b$ ) (Table 1) with no time restrictions. These two databases contain journals that cover a wide range of topics from areas of relevance to answer the research question. An explicit search strategy was employed to obtain the data [124]. Abstracts and full text articles in scholarly peer reviewed journals were searched for in EBSCO-HOST. Abstracts and full text of reviews, peer reviewed articles, conference papers, and editorials were searched for in Scopus.

\subsection{Data Analysis}

A directed content analysis [126-129] was used to add knowledge regarding the phenomenon investigated, namely the EDI discourse, and disabled people at universities that "would benefit from further description" [129] (p. 1281). All of the abstracts were first read to identify the ones that fit the inclusion criteria. Full text articles were then obtained of the abstracts flagged as fitting the inclusion criteria. All the abstracts and the full texts available were uploaded into the qualitative analysis software ATLAS.Ti $8^{\mathrm{TM}}$ to perform a directed content analysis in four stages.

In stage 1 , the data obtained through strategies 1-3 were analysed using pre-set codes to ascertain whether the data covered disabled students, non-academic staff, or academic staff in relation to EDI. In strategy 4, the same codes were used, but flagged whether the data covered disabled students, non-academic staff, or academic staff in relation to EDI and outside the framework of EDI.

In stage 2, every term in the data that could be seen to describe a disabled person was recorded if that disabled person and the term disability was covered within the context of universities.

In stage 3, a directed content analysis was employed to analyse the data that were obtained through strategy 1-4 keeping in mind the research question and the existing literature. We generated two top themes in relation to the research question and the results of the search strategies. Theme 1 (T1): what was said in relation to disabled people at universities in relation to the EDI frameworks or the EDI phrases. T1 reflects the results obtained through search strategies 1-3. Theme 2 (T2): what was mentioned in relation to disabled people at universities without specifically mentioning EDI phrases or frameworks, 
but what could be seen as useful for EDI discourses. T2 reflects the results obtained through search strategy 4.

Keeping in mind the research question and our knowledge of the EDI literature on the one hand and the literature around the situation of disabled people in universities on the other hand, we further generated the following sub-themes that we applied to both T1 and T2: "could be or is used also for disabled people" (ST1), intersectionality (ST2a), including disability/disabled people (ST2b), problem with intersectionality including disability/disabled people (ST2c), problem with the EDI framework in general (ST3a) problem with the EDI framework in relation to disabled people (ST3b), "evaluation of the situation" (ST4), positive evaluation of the situation (ST4a) problems noted for disable people in universities (ST5), solutions proposed for the problematic situation (ST6), problem with or impact of definition of disability (ST7), and identity and disabled people (ST8). We also analysed whether there were other subthemes appearing that were not on our predeveloped list.

The trustworthiness measures include confirmability, credibility, dependability, and transferability [130-132]. Differences in coding of the qualitative data were few and discussed between the authors (peer debriefing) and revised, as needed [131]. Confirmability is evident in the audit trail made possible by using the Memo and coding functions within ATLAS.Ti $8^{\mathrm{TM}}$ software. As for transferability, the methods description gives all required information for others to decide whether they want to apply the keyword searches on other data sources, such as grey literature, or other academic literature or other languages or want to apply other research questions on the identified data in this study.

\subsection{Limitations/Boundaries}

The search was limited to two academic databases and English language literature. The findings are not intended to be generalized to the whole academic literature, non-academic literature, or non-English literature. However, these findings allow for conclusions to be made within the parameters of the searches. It is important to note one boundary: this study focused on the engagement of EDI focused academic literature with disabled people at universities. There are of course many studies that cover the situation of disabled students, non-academic staff, and academic staff in universities without using the EDI terms or the EDI frameworks. Many studies are mentioned in the background section that could be used by EDI discussions to inform EDI actions related to disabled students, non-academic staff, and academic staff. However, given that so many English languagebased universities by now use EDI as a term including positions that are generated as high as on the Provost level, and given that proposals for actions are linked to EDI language including EDI frameworks such as Athena SWAN, and that EDI, as such, covers all levels of universities (student, non-academic staff, and academic staff), EDI becomes a brand and therefore it is important to focus on the EDI area to see how they engage with disabled people. Now, EDI might be visible in English language-based universities as a concept. This study cannot judge whether the same is evident or on the horizon in non-English based universities.

\section{Results}

The result section is divided in two main parts: one reporting on the data that were obtained through strategies 1-3 and reflecting theme 1 (T1) (what is said in relation to disabled people at universities in relation to the EDI frameworks or the EDI phrases-Section 3.1) and the second one reporting on the data that were obtained through strategy 4, which reflects theme 2 (T2) (what was mentioned in relation to disabled people at universities without specifically mentioning EDI phrases or frameworks, but what could be seen as useful for EDI discourses-Section 3.2). See Figure 1. 


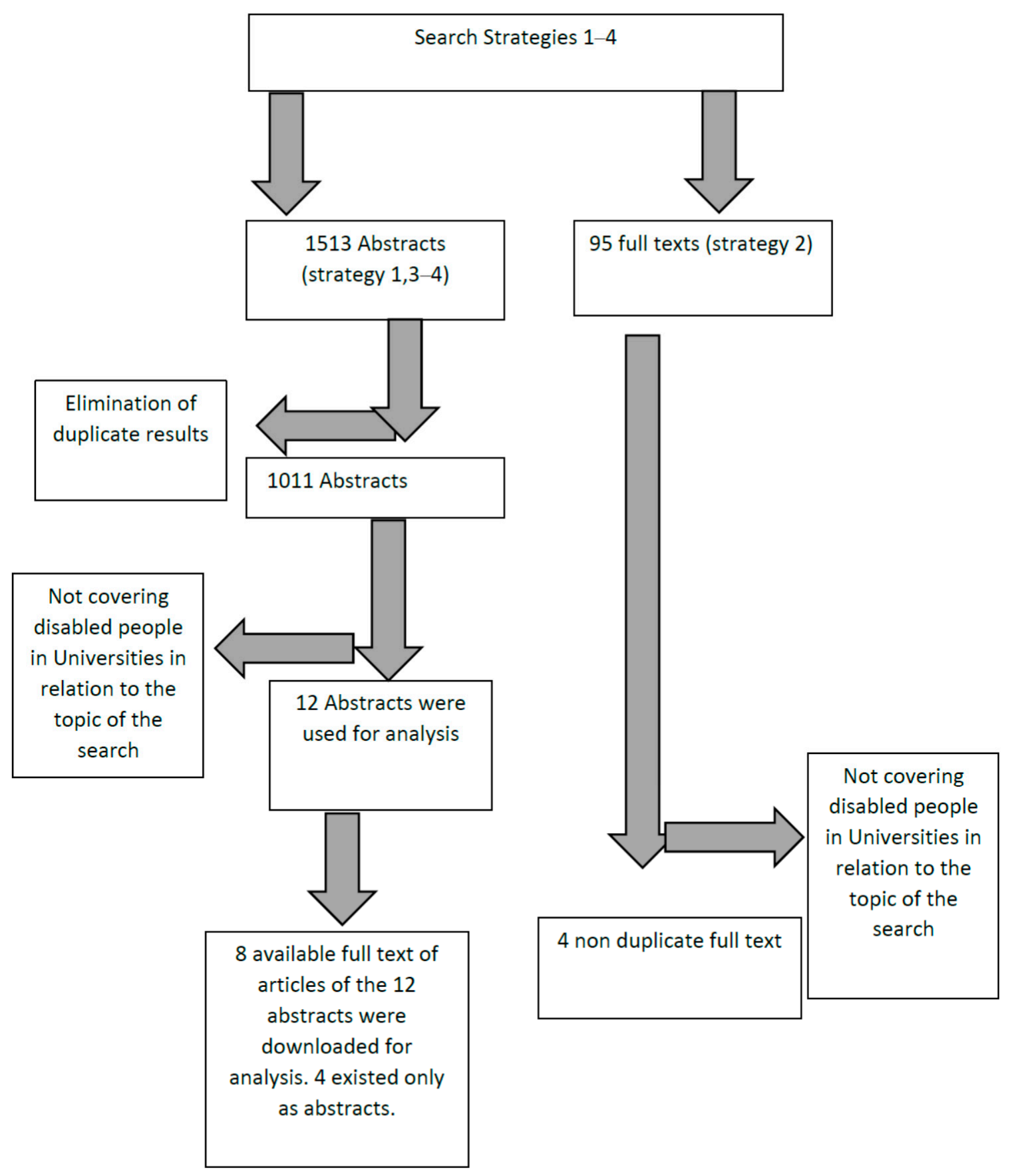

Figure 1. The flow chart of the selection of academic abstracts and full text articles for qualitative analysis.

Each of these two main sections are divided into three subparts. In the first part, hit counts are outlined on who is mentioned (disabled student, non-academic staff, academic staff, and disability as a general term). The second part gives hit counts for what terms are used to describe disability/disabled people, whereby the understanding of disabled people, as quoted in Section 1.2 [62,67], is used. In the final third part, the subthemes, as outlined in Section 2.5, present in the relevant content linked to theme 1 and 2 is reported.

As to reporting the result of subthemes, we decided not to organize the data by subthemes as headers/sub-headers, but, rather, we organized the data by what subthemes we found for each source (abstract and article). 


\subsection{Strategies 1-3: Relevant Content of EDI Discussions Engaging with Disabled People}

Only two relevant full text articles were found through strategy 2a, which covered the EDI framework "Athena SWAN", UK, and two relevant full text articles through strategy 2e covered the National Science Foundation's "NSF ADVANCE" (USA) EDI framework. Strategies $2 b-d$, which covered the EDI frameworks of the American Association for the Advancement of Science program "See change with STEMM Equity Achievement" (SEA-Change), USA; the "Dimensions: equity, diversity and inclusion", Canada; and, the "Science in Australia Gender Equity" (SAGE), Australia, as well as strategies 3a and 3b, which covered the phrases "equity, diversity and inclusion" and "equality, diversity and inclusion" did not yield any relevant data.

\subsubsection{Frequency of Certain Topics Engaging Different Groups of Disabled People} (Strategies 1-3)

Table 2 shows that strategies 1-3 generated no positive results for abstracts as the coding unit and only two for the full text as the coding unit.

Table 2. Frequency of relevant topics engaging different groups of disabled people (strategies 1-3).

\begin{tabular}{|c|c|c|c|c|}
\hline Topic & $\begin{array}{l}\text { Topic Engaged with } \\
\text { Disabled Students at } \\
\text { Universities }\end{array}$ & $\begin{array}{l}\text { Topic Engaged } \\
\text { with Disabled } \\
\text { Non-Academic Staff } \\
\text { at Universities }\end{array}$ & $\begin{array}{l}\text { Topic Engaged with } \\
\text { Disabled Academic } \\
\text { Staff at Universities }\end{array}$ & $\begin{array}{l}\text { Topic Mentioned in } \\
\text { Relation to Disability } \\
\text { but Still within the } \\
\text { Boundary of } \\
\text { Universities without } \\
\text { Going into Details }\end{array}$ \\
\hline $\begin{array}{l}\text { Strategy 1: Abstract: } \\
\text { Athena SWAN }\end{array}$ & 0 & 0 & 0 & 0 \\
\hline $\begin{array}{l}\text { Strategy 2a: Full text: Athena } \\
\text { SWAN and "disab*" }\end{array}$ & 0 & 0 & 0 & 2 \\
\hline $\begin{array}{l}\text { Strategy 2b: Full Text: "See } \\
\text { change with STEMM Equity } \\
\text { Achievement" } \\
\text { Strategy 2cFull Text: }\end{array}$ & 0 & 0 & 0 & 0 \\
\hline $\begin{array}{l}\text { "Dimensions: equity, diversity } \\
\text { and inclusion" } \\
\text { Strategy 2d Full Text: }\end{array}$ & 0 & 0 & 0 & 0 \\
\hline $\begin{array}{l}\text { "Science in Australia Gender } \\
\text { Equity" }\end{array}$ & 0 & 0 & 0 & 0 \\
\hline $\begin{array}{l}\text { Strategy 2e Full Text: “NSF } \\
\text { ADVANCE" } \\
\text { Strategy 3a Abstract: Content }\end{array}$ & 0 & 0 & 2 & 0 \\
\hline $\begin{array}{l}\text { linked to the phrase "equity, } \\
\text { diversity and inclusion" } \\
\text { Strategy 3b Abstract: Content }\end{array}$ & 0 & 0 & 0 & 0 \\
\hline $\begin{array}{l}\text { linked to the phrase "equality, } \\
\text { diversity and inclusion" }\end{array}$ & 0 & 0 & 0 & 0 \\
\hline
\end{tabular}

3.1.2. Words Used to Describe Disabled People in Data Obtained by Strategies 1-3

Within the full text obtained through strategy $2 a$, the disability related terms used were "disability" [133], "range of disabilities" [133], and "disability" [134].

Within the full text obtained through strategy 2e, the disability related terms used were "disability" [135], and "deaf education" [136], "Institute for the Deaf" [136] "deaf and hard of hearing women faculty" [136], "women who are deaf and hard of hearing" [136], deaf and hard of hearing (D/HH) [136], "World Federation of the Deaf" [136], Deaf Professor [136], "Deaf Women in Academia" [136], "Female Deaf Faculty" [136], and Deaf and Hard of Hearing Faculty" [136]. 


\subsubsection{Subthemes of Relevant Content of EDI Discussions Engaging with Disabled People}

Within the relevant content found through strategy 1-3, we did not find subthemes beyond what we already pre-developed. Furthermore, of the pre-set subthemes, we did not find a problem with intersectionality, including disabled people (ST2c), problem with the EDI framework in general (ST3a), problem with or impact of definition of disability (ST7), and identity and disabled people (ST8). Regarding the two relevant results from strategy 2a, in the first full text article [133] it is argued that the Athena SWAN charter was criticized for its limited scope of ignoring "intersecting equalities" (T1, ST2a) and the authors noted that the owners (Equality Challenge Unit) of the Athena SWAN Charter tried to introduce intersectionality in 2015 (T1, ST2a), whereby the authors [133] quoted the following that included disability as a factor influencing ones identity and situation:

"People's identities are shaped by several factors at the same time, creating unique experiences and perspectives. These factors include among others age, disability, gender identity, race, religion and belief, and sexuality. Institutions should be mindful of this intersectionality when exploring issues and developing solutions. (Equality Challenge Unit, 2015, p. 35)" [133] (p. 1201) (T1, ST2b)

At the same time, the authors argued further that, despite the 2015 guidance, not enough had been done to support the intersectionality [133] (T1, ST2a).

In the second full text article obtained through from strategy 2a, the authors compared the Athena SWAN with gender equality interventions in the European Research Area and make the case that Athena SWAN includes disability:

"Athena SWAN has a somewhat broader focus as regards the target population, including also professional and support staff and students as well as considering the intersectionality of gender and other aspects of identity, such as sexuality, race, disability, age and religion" [134] (p. 5) (T1, ST1)

However, the authors do not indicate whether the European Research Area equality interventions include disability as a factor (T1, ST3b).

Regarding strategy 2e, in one full text, the authors acknowledge the intersectionality of gender with other factors, whereby one factor mentioned is "disability" (T1, ST2b). The authors argue further that the reason why women are still underrepresented in STEM is linked to the intersectionality of gender with other factors, namely "disability" [135] (T1, $\mathrm{ST} 2 \mathrm{~b})$ and (T1, ST1). The full text does mention the same argument, but it does not add more content not already in the abstract.

The second full text covers a professional development workshop series "for all tenuretrack women faculty on campus as well as targeted workshops for women of colour and deaf and hard of hearing women faculty" [136] (p. 1) at Rochester Institute of Technology (T1, ST1) (T1, ST4). The authors argue that a self-study conducted at the Rochester Institute of Technology that was used as a data source for developing the workshops indicated that the realities of women who are deaf and hard of hearing have been obscured by scholarship that is devoted to women as a whole [136] (T1, ST5). The fact that they focused on deaf and hard of hearing people in their university might be because they house the National Technical Institute for the Deaf (NTID), with 31 deaf and hard of hearing (D/HH) women faculty. Based on the self-study, they developed a specific workshop covering the intersectionality of women and deaf and hard of hearing (T1, ST6). The workshops focused on national and international networking and professional development and advancement in academia (T1, ST6). The authors highlighted it as innovative that one of the workshops was held as per Teleconferencing noting, which was needed due to the low density of deaf and hard of hearing academic population in North America and beyond (T1, ST6). The authors highlighted that " $\mathrm{D} / \mathrm{HH}$ males, individuals of colour, and hearing women began to request access to the D/HH Connectivity Series events" [136] (p. 6) (T1, ST6), as they saw the content also of use to them $(\mathrm{T} 1, \mathrm{ST} 6)$. 
3.2. Strategy 4: Coverage of Disabled People at Universities without Specifically Mentioning EDI Phrases or Frameworks but What Could Be Seen as Useful for EDI Discourses

Regarding strategy $4 a$, seven abstracts had relevant data and, for four of these abstracts, the full text of the article was also available. As to strategy $4 \mathrm{~b}$, five abstracts had relevant data and for four of these abstracts the full text of the article was also available.

\subsubsection{Frequency of Certain Topics Engaging Different Groups of Disabled People} (Strategy 4)

Table 3 shows that downloaded data that were obtained through strategy 4 limitedly engaged with disabled people at university and even less cover disabled people at universities in conjunction with EDI.

Table 3. Frequency of relevant topics engaging different groups of disabled people (strategy 4).

\begin{tabular}{|c|c|c|c|c|}
\hline Strategy Topic & $\begin{array}{c}\text { Topic Engaged with } \\
\text { Disabled Students at } \\
\text { Universities }\end{array}$ & $\begin{array}{c}\text { Topic Engaged } \\
\text { with Disabled } \\
\text { Non-Academic Staff } \\
\text { at Universities }\end{array}$ & $\begin{array}{l}\text { Topic Engaged with } \\
\text { Disabled Academic } \\
\text { Staff at Universities }\end{array}$ & $\begin{array}{l}\text { Topic Mentioned in } \\
\text { Relation to Disability } \\
\text { but Still within the } \\
\text { Boundary of } \\
\text { Universities without } \\
\text { Going into Details }\end{array}$ \\
\hline $\begin{array}{l}\text { Content found in the } \\
\text { abstracts obtained through } \\
\text { strategy } 4 \text { a and the available } \\
\text { full text linked to the } \\
\text { abstracts that engaged with } \\
\text { disabled people at } \\
\text { universities in conjunction } \\
\text { with EDI }\end{array}$ & 0 & 0 & 0 & 0 \\
\hline $\begin{array}{l}\text { Content found in the } \\
\text { abstracts obtained through } \\
\text { strategy } 4 \text { a and the available } \\
\text { full text linked to the } \\
\text { abstracts that engaged with } \\
\text { disabled people at } \\
\text { universities }\end{array}$ & 5 & 0 & 2 & 0 \\
\hline $\begin{array}{l}\text { Content found in the } \\
\text { abstracts obtained through } \\
\text { strategy } 4 \text { b and the available } \\
\text { full text linked to the } \\
\text { abstracts that engaged with } \\
\text { disabled people at } \\
\text { universities and EDI }\end{array}$ & 0 & 1 & 0 & 1 \\
\hline $\begin{array}{l}\text { Content found in the } \\
\text { abstracts obtained through } \\
\text { strategy } 4 \text { b and the available } \\
\text { full text linked to the } \\
\text { abstracts that engaged with } \\
\text { disabled people at } \\
\text { universities }\end{array}$ & 3 & 1 & 0 & 0 \\
\hline
\end{tabular}

\subsubsection{Words Used to Describe Disabled People in Data Obtained by Strategy 4}

Within these four full text articles and three abstracts obtained through strategy $4 a$, the disability related terms present were: "neurodiversity" [137], "Attention Deficit Hyperactivity Disorder (ADHD)" [137], "students with ADHD" [137], "students' disabilities" [138], "invisibility of their disabilities" [138], "students with a disability" [139], "disability status" [140], "individuals with disabilities" [141], "students with disabilities" [141], "students with learning disabilities" [142], and "disability" [143]. 
Within these four full text articles and one abstract obtained through strategy $4 b$, disability related terms present were: "students with disabilities" [144], "disability" [145] "disability" [146], "disabled people" [147], "disabled staff" [147], "disabled students" [148], "hidden disability" [145], "mental health issues" [145], "HIV/AIDS" [145], "those with disabilities" [145], or "epilepsy" [145].

\subsubsection{Subthemes of Relevant Content for EDI Discussions Engaging with Disabled People}

Within the relevant content found through strategy 4, all but ST3a (problem with the EDI framework in general) and ST3b (problem with the EDI framework in relation to disabled people) were present. Regarding strategy 4a, seven abstracts had relevant data and for four of these abstracts the full text of the article was also available. Within these four full texts, the following content was relevant: one article investigated the impact of internationalisation of disabled students [139] (T2, ST4; T2, ST5) using Murray-Seegert's "ecological theory of diversity to explore the ways that cultural factors affect opportunities for inclusion of students with a disability in the higher education sector" [139] (p. 217) (T2, ST4; T2, ST5; T2, ST6). The authors acknowledged that the composition of 'disability' is changing due to the broad definition of 'disability' with an increase in "learning disabilities, mental health conditions, chronic fatigue syndrome" [139] (p. 221) (T2, ST7). The authors discussed the problem of regret of disclosure, highlighting various studies [139] (p. 221) (T2, ST8). The second one used the theoretical framework of the capability approach to make a case for the admission of disabled students to higher education and that higher education "should consider opportunities (capabilities) for all students to live the lives that they have reason to value (valued functioning's)" [138] (p. 451) (T2, ST6). The authors argued that "students are different in many ways and this means that simply providing equal access to equivalent resources does not necessarily lead to equal outcomes, as diverse students are differently able to convert resources into desired outcomes depending on their personal characteristics, social and environmental circumstances" [138] (p. 451) (T2, ST5; T2, ST7; T2, ST8). The authors argued that the capability approach is "attentive to diversity, equity and inclusivity in abilities to transform means into achievements, it is preferable to views that focus on equality of means. Therefore, CA aims to obtain outcomes that people will value while empowering them" [138] (p. 452) (T2, ST6). The article also highlighted that data on intersectionality between one's ability and other characteristics, such as race, ethnicity, and socio-economic status, is needed [138] (T2, ST2c). A third one covered a Research Experience for Undergraduates (REU) Site that was funded by the NSF Division of Engineering Education and Centers and concluded "that participating in the program enhanced students' (1) interest in engineering research, (2) interest in pursuing graduate studies in engineering and (3) feelings of belonging in engineering" [137] (p. 1) (T2, ST6). A fourth one mentioned that "retention, especially of under-represented populations through the first year university, is an on-going concern in engineering programs" [142] (p. 15.362.2) (T2, ST4). Regarding disabled people, the authors covered learning disabled students [142] (T2, ST5). The authors in their literature review outlined various pre-existing biases, questioning the limited (medical) scope of the definition of learning disability (T2, ST7), and that the disabling learning environment must be addressed [142] (T2, ST5).

Three were only available as abstracts, whereby one abstract dealt with disabled students in relation to accommodation in fieldwork [141] (T2, ST5; T2 ST6). Only two abstracts (both no full text available) moved beyond students. One, called "Lowering barriers for all underrepresented chemistry professor", covered a 2011 National Diversity Equity Workshop organized by Open Chemistry Collaborative in Diversity Equity (OXIDE) [143] (T2, ST5 and T2, ST6) and another one covered the 2017 workshop with the same focus [140] (T2, ST5 and T2, ST6) without going into details.

Regarding strategy $4 \mathrm{~b}$, five abstracts had relevant data and for four of these abstracts the full text of the article was also available. As to the four full texts, one focused on disabled students in Cyprus private tertiary colleges [144] noting variability in the provision (T2, ST5), mainly due to the lack of common and consistent procedures with regard to 
identifying disability (T2, ST7) and responding to students' needs effectively [144] (T2, ST5). The second article argued that diversity, inclusion, and equality are important values in UK universities back to the 1963 Robbins Report (T2, ST1). The author noted that the diversity related to disabled students is increasing [146] (T2, ST1), but also concluded that university value statements related to diversity, inclusion, and equality have little effect "on an institution's behaviour or practice" [146] (p. 281) (T2, ST1, T2, ST5) and that "there was no clear connection between an institution mentioning diversity in their statements and a particularly diverse student body [146] (p. 281) (T2, ST1; T2, ST5). A third article focused on career progression into leadership by disabled staff [147], and concluded "that disabled staff in HE do not yet have equal opportunities for progression into leadership roles compared with their non-disabled peers" [147] (p. 1027) (T2, ST5). This article found some positive experiences by participants (T2, ST4a), but also identified barriers to progression into leadership positions: a lack of awareness of equality and diversity among managers and colleagues, inadequate professional development opportunities, and the competitive organisational culture of management that could impact on their health and work-life balance" [147] (p. 1027) (T2, ST5). The authors cited in the background section many actions that an organization could take to improve the situation of disabled students, non-academic staff, and academic staff that is already mentioned in the literature: such as improving the organizational culture, identify and eliminate social barriers, such as reactions of co-workers, leadership by senior disabled non-academic and academic staff to be open about their 'disability', to have senior members of non-academic and academic staff to explicitly promote disability equality issues', formal and informal mentoring, shadow senior management teams, and disabled role models, disabled non-academic, and disabled academic staff networks, and support structures that are similar to disabled students [147] (p. 1027) (T2, ST6). The authors argued that the identity of the disabled non-academic and academic staff is an important issue (T2, ST7), including the intersectionality (T2, ST2b) within disabled non-academic and academic staff as they are also part of other identities, whereby the response to career advancements will also react to these other identities, and the authors noted "how the impact of their particular impairment or condition interacts in complex ways with social barriers, resulting in them being disadvantaged in terms of their prospects for career progression" [147] (p. 1039) (T2, ST2c; T2, ST5). In their interviews, the authors found that the answers reflected many of the issues already mentioned in the literature, but also highlighted that the very meaning and what counts as leadership is worthy of more investigations [147] (T2, ST5; T2, ST6). Finally, the authors suggest that the Athena SWAN model could be applied to disabled non-academic and academic staff (T1, ST1) citing the Athena SWAN Charter principle that "academia cannot reach its full potential unless it can benefit from the talents of all" [1,147] (p. 1040) (T1, ST1).

Regarding the fourth one, one focus is on intersectionality (T2, ST2; T2, ST2a), highlighting many problems (T2, ST2c), for example, in relation to "disability" especially "hidden disability", such as mental health issues, HIV / AIDS, and epilepsy the problem of speed is mentioned [145] (T2, ST2c). The article provides various suggestions for actions by academic workers and suggests already available tools and processes, such as networks, trade unions, international version of the "Race Equality Charter and Athena SWAN, or disability inclusion movements, all of which strongly promote diversity and equality" [145] (p. 63) (T2, ST6; T1, ST6). They suggest modifications of how to measure research or teaching and learning capabilities to empower minority groups, including "those with disabilities" (T2, ST6) [145].

As to the one only accessible as an abstract [148], the authors argue that disabled students have been invisible in higher education for a long time and encountered problems with entering HE and obtaining equitable treatment once in (T2, ST5), but that this is changing for the better in the UK (T2, ST4a). They argue that, for changes to continue that physical access, knowledge of non-academic and academic staff on disability issues is essential, greater attention should be paid to quality of teaching and learning, and that one should listen to disabled students and their organizations (T2, ST6). 


\section{Discussion}

Given the low numbers of abstracts that were found for the EDI framework "Athena SWAN", UK, the low to non-existence of abstracts and low numbers in full text searches for the American Association for the Advancement of Science program "See change with STEMM Equity Achievement" (SEA-Change), the "Dimensions: equity, diversity and inclusion" (Canada), the "Science in Australia Gender Equity" (SAGE, Australia), and the National Science Foundation's "NSF ADVANCE" (USA), these findings suggest a disconnect between the implementation of these EDI initiatives and an academic evaluation of these implementation, which is problematic, but also suggests an opening for many studies. However, given the focus of this study, it is much worse that the search strategies found no results for abstracts as the coding unit and only four results for the full text as the coding unit while searching the EDI frameworks Athena SWAN, SEA-Change, Dimensions: equity, diversity and inclusion, SAGE, Australia and NSF ADVANCE and the phrases "equity, diversity and inclusion" and "equality, diversity and inclusion" in relation to disabled students, disabled non-academic staff, or disabled academic staff. In the case of EDI frameworks that focus on a specific group, such as Athena SWAN and "Science in Australia Gender Equity" (SAGE, Australia), one might expect small to no hits in relation to disabled people at universities as they do not focus on disabled people at universities as such, but others, such as "Dimensions: equity, diversity and inclusion" (Canada), See change with STEMM Equity Achievement" (SEA-Change), NSF ADVANCE" (USA) do cover disabled people. Furthermore, there is no reason why the phrases "equity, diversity and inclusion" and "equality, diversity and inclusion" should return no hits for disabled people in universities. Even if the abstracts were searched for the EDI terms present in the phrases "equity, diversity and inclusion" and "equality, diversity and inclusion" not as phrases, but as being present in a given abstracts as individual terms, only one abstract covering disabled non-academic staff, two abstracts covering disabled academic staff, and nine abstracts covering disabled students were found.

Many academic articles providing the data that are needed to make EDI for disabled students, non-academic staff, and academic staff a success should have been found in articles that focus on EDI for several reasons: disabled students, non-academic staff, and academic staff encounter severe problems and barriers in post-secondary institutions [25-30,68,70-75,79,82-90,93-98,149-157], including the lack of ability identity security (have a positive identity about ones set of abilities) [22,68,70-73] and the numbers of disabled academic faculty are too low (for Canada see [31-33]). Policies are to be informed by evidence and policies can influence what is researched [39,158-163] and groups that are involved in EDI such as members of Universities Canada stated that they will "be guided by evidence in addressing problems that discourage members of under-represented groups to advance" [44]. The problematic results are discussed through the premise of EDI, as evident in policy document, EDI problems identified for other EDI groups beyond disabled people, and international and national science policy documents, such as the 2017 "UNESCO Recommendation on Science and Scientific Researchers" [40,164] and the 1999 "UNESCO/ICSU World Conference on Sciences" [29,30].

\subsection{The Premise and Problems of EDI}

It is recognized that, to advance EDI, the following abilities are needed: the ability of "an in-depth and intersectional understanding of inequity, discrimination and exclusion" $[24,46]$, the ability to experience equitable, inclusive and unbiased systems and practices [47], the ability to perform "specific, measurable and sustainable actions" [47], to generate qualitative and quantitative data, to measure, monitor, understand, and publicly report on the challenges and progress made [47], to collect and analyse the data [45], and to identify barriers to EDI on all levels and make visible and promote best practices of EDI [44]. This list of abilities demands many actions, including the production of data on the topic of EDI and disabled people. However, this study's findings indicate a total disconnect between what should be done and what is done. The barriers of EDI in relation 
to disabled people were not identified and best practices were recommended. Neither were the data, measures, or identifications of biases, and how to make the system unbiased found. Furthermore, intersectionality was not presented with the literature covered in this study.

In the EDI academic literature, many problems are identified, and solutions proposed in relation to race and gender EDI; for example, a lack of race and gender is identified in STEM education [48-53]. One could apply the reasoning in the literature around STEM and race and gender to the discourse around EDI, STEM, and disabled people, such as making sure that disabled people are enticed to think about university and being STEM or nonSTEM related researchers. Such enticement should start in junior high schools by exposing disabled students to role models that they can relate to; for example, a deaf student would need a deaf role-model, or a wheelchair user would need a wheelchair user role-model, etc. This is needed, because, given the broad definition used in EDI, the very barriers, solutions, and realities between the different groups covered under the disability definitions are vastly different. Indeed, another study looking at the coverage of disabled undergraduate students as researchers showed a lack of such coverage [26] fitting with the findings of this study. Many of the 10 rules to build an anti-racist lab [50] could be applied to build a lab that is not using ability expectations in a disabling way and supports disabled people. The 10 rules could be rephrased and amended, as follows: lead discussions that increase literacy on the topic of disabled people at universities and the disabling issues that they face, add to the discussions, such as harassment, bullying, and microaggressions with an angle addressing the disabling use of ability expectations, publish and write grants with people targeted by disabling use ability expectations, mentor, amplify the voices experiencing disabling use of irrelevant ability expectations, support disabled people in their organizing efforts, recruit them as students and non-academic and academic staff, flexible research agenda, advocate for ability diverse leadership in science and beyond (see [147]), hold the powerful accountable, and do not expect gratitude and make visible the biases in what is funded. One article covering racialized and Indigenous academics at Canadian universities outlined many problems, such as privileging certain knowledge, evidence, research questions, and methods with an impact on the diversity of journals open for oneself to publish in; the absence of courses covering relevant content related to them; disproportional presence in EDI efforts and mentoring of people of one's minority; low self-esteem, physical and mental health impacts, serious considerations of leaving academia, severely affected career trajectory and engagement, problems with why and how one is asked to be part of EDI efforts, and biased teaching evaluation of racialized and Indigenous faculty [165]. All of these points can and should be applied to disabled academics. The following identified problems and actions that are needed in relation to race and gender are also applicable to disabled students and disabled academics: representation in textbooks [56] (for literature on this related to disabled people, see [166-170], address leaky pipeline (such as go to junior and senior high schools to entice disabled students), go beyond academia, make women visible [51] (make disabled people visible), move towards highcontext approaches to learning [52], institutional culture changes in academia [53], fighting implicit biases and microaggressions [54] (by changing existing modules on harassment and bullying that often leave out disabled people, increase intersectionality and moving away from the "superwomen" [57] (p. 1779) (see the many similar discussions around the supercrip [79,171-174]), and the ability to identify correctly and deal with "implicit bias", "status leveling", "tokenism", and "failure to differentiate" [58].

Regarding "color-blind racial attitudes", change is needed [58], in relation to disabled people one could talk about ability-blind disabling attitudes by not seeing the ability privilege of the so-called 'non-impaired'. Many EDI documents and webpages use the language of accommodation that disabled people receive in universities (e.g., [175-178]). Within Canadian universities, the accommodation language is taken from the employment equity act, which states: "and includes persons whose functional limitations owing to their impairment have been accommodated in their current job or workplace" [61]. However, 
every person who shows up at the university receives and needs accommodations. (i.e., every human needs a washroom at work... ), so everyone is especially ability deficient and needs to be accommodated. Subsequently, we also use specific language to 'accommodate' others not using the label of 'impairment' and without blaming the person, such as "worklife balance" [179-181]. To call out the accommodation of disabled people as something special while ignoring the ubiquitousness of accommodation of others highlights the ability privilege that many take for granted (e.g., that the ones with legs have access to washrooms) and the prevalent unconscious and conscious ability privilege bias in the EDI narrative. According to the EDI office of the university of Toronto, "Equity implies that in order to be fair and just, we must acknowledge that people are different and therefore, need different support in order to have equal access to opportunities" (caged webpage, text has been taken out [182]) or newer text "Equity is the fair and respectful treatment of all people and involves the creation of opportunities and reduction of disparities in opportunities and outcomes for diverse communities. It also acknowledges that these disparities are rooted in historical and contemporary injustices and disadvantages" [183]. As such, the accommodation part of the EDI definition of disabled people in Canada clearly exhibits ability inequity, especially of the second aspects of the definition, which is defined as (a) an unjust or unfair distribution of access to and protection from abilities generated through human interventions and (b) an unjust or unfair judgment of abilities intrinsic to biological structures, such as the human body [112]. It is stated that one must have training to eliminate conscious, unconscious, implicit bias "based on race, ethnicity, gender, or sexual orientation" [58] (p. 287). It is just as needed to have training to eliminate biases that are related to abilities and ability privileges, given that abilities are one dimension of, and human identity and that ability is interrelated with other dimension of human identity. There are ability expectation exercises [184] that could be used to increase the literacy and awareness on what abilities one takes for granted (such as accessing washrooms), which, for wheelchair users, are treated as accommodation if the washrooms are adapted ignoring that the washroom itself is an accommodation for humans, in general.

\subsubsection{Microaggression}

Various authors have outlined microaggression as a problem [10,54,165], including Canadian research funding agencies who provide the following definitions for microaggression "brief and common verbal, behavioural or institutional actions that play into stereotypes or discrimination against a group of people, often from underrepresented groups" [45]. Many of the problems that are outlined in the last section, of which all are also applicable to disabled students, non-academic staff, and academic staff can be seen to feed into microaggressions. Indeed, some recent theses cover disability microaggression, including microaggression that is encountered by disabled faculty [185-187]. One thesis used existing microaggression characteristics and modified them to develop a disability microaggression scale [185] and another thesis employed an ableist microaggression scale [187]. Minority stress theory is used to argue that minority groups face "chronic sociocultural stressors distinct from those faced by faculty in general", whereby the following stressors and negative external events and conditions are identified, "expectations of rejection or mistreatment, vigilance and desire to conceal identity and the internalization of social stigma" [10] (p. 4). If one looks at disabled students, non-academic staff, and academic staff, the factors identified around ethnic minorities and microaggression can all be seen to be present around disabled students, non-academic staff, and academic staff. Subsequently, disabled students, non-academic staff, and academic staff might be even more impacted, given that, according to Statistics Canada, 35\% of disabled university professors, instructors, teachers, or researchers "experienced unfair treatment or discrimination in the past 12 months and $47 \%$ saw themselves "subjected to at least one type of harassment in the past 12 month" [100]. With that, the numbers for disabled university professors, instructors, teachers, or researchers experiencing unfair treatment, discrimination, or harassment are the highest of all groups recorded. 


\subsubsection{The Issue of Identity}

Covering ethnic-racial minorities, identity process theory and Rotter's locus of control theory are used to highlight and discuss the problems with losing one's personal and social identity [188]. It is argued that discrimination and encounter with negative imagery of oneself in academia can lead to academic disengagement due to having to compromise in their personal and social identity [188]. As such, one can apply the same reasoning and identity process theory and Rotter's locus of control theory used for ethnic-racial minorities to argue that not being able to have a positive personal and social identity leads to problems [188] for disabled students, non-academic staff, and academic staff. Therefore, it is a problem that EDI documents in many places follows a deficiency language of disabled people on the identity level of the body (body deficient by default), but also on the identity level of who causes the problem (the deficient person causes the problem) [175-178]. In Canada, this is due to EDI discourses following the Employment Equity Act definition of disabled people [61]. If compromising one's personal and social identity leads to academic disengagement for ethnic-racial minorities, one should expect the same for disabled students, non-academic staff, and academic staff. Indeed, it is well reported that disabled people experience discrimination and a lack of ability identity security (the ability to be positive about ones set of abilities) [112] in academia [22,71-73], and the negative impact of deficiency, biomedical language to define disabled students has been flagged for some time $[68,70,71]$. It is argued that "institutions must simultaneously address students' fundamental needs of food and housing, safety and security, peer relationships and social worth, interpersonal relationships, self-esteem and respect as they seek to enhance students' educational progress and guide students to become all they are capable of being" [189]. If that is the case, then EDI must better the situation of disabled students, including how they are labelled, as that directly impacts self-worth. Self-worth includes that one is not forced to accept a deficiency understanding of oneself, so that one should experience ability identity security.

Impairment as a default position "other's" the person from the 'non-impaired'. Many disabled people refuse to see themselves as deficient, such as in Deaf culture and neurodiversity. Given that, according to identity theory, there are many social factors that define the self [113], the question is which factors are in play that make the negative definition of disabled people the default position. Identities are social products and they are important for self-meaning [114], which raises the question of the consequence if the medical deficiency identity is the social product and if one is pushed into the self-meaning of deficiency.

Given that identity is a "source of motivation for action particularly actions that result in the social confirmation of the identity" [114] (p. 242), one might look for action of oneself that validates the social validation of one's medical identity. If one is pushed toward the deficiency identity due to the action of others, one might internalize ability identity oppression (the acceptance of a negative self-image of oneself) and seek action to act accordingly. If the negative labelling is the default, then disabled students, non-academic staff, and academic staff have the option to accept or even internalize the ability identity oppression to belong not only to the institutional culture and not being othered or risk being othered if they do not agree. Not being allowed to experience ability identity security sets the stage for an ability identity conflict between disabled people who self-identify with a medical identity and the ones that do not. Indeed, there are two groups that disabled students, non-academic staff, and academic staff can identify with: the ones who see their body as impaired and see themselves to be disabled by the disabling use of irrelevant ability expectations in academia [71-73], and the ones who do not identify with the negative labelling of their body and its set of abilities (e.g., Deaf culture, neurodiversity). As such, the default premise of being seen as defective is disempowering, and it does not allow for the self-determination of one's body image. If EDI wants to build a culture of belonging for disabled students, non-academic staff, and academic staff, it must allow for both selfunderstandings of one's body. It should acknowledge that disabled people are the only ones that are defined in a negative way by default in the EDI discourse given the definition 
that is used for disabled people used in EDI. None of the other groups that are covered by EDI have a negative label attached to their identity (ethnic minority, women, or indigenous people). Indeed, eliminating negative stereotypes is a goal of EDI [190]. Negative labelling the identity of others is one form of stereotyping. Therefore, it is problematic that disabled people at university cannot choose how they perceives one's body $[23,68,69]$. Indeed, in one thesis, it was noted that the body identity overshadows everything else [191]:

"Vance (2007) discussed the experiences of faculty and staff with disabilities in a book she edited on college faculty and staff with disabilities. In her opening pages, Vance states, "we [disabled] share the repercussions of having only one part of our identity, the disability, overshadow all other parts of our identities, thus impeding our attempts to fully pursue professional endeavors" (p. 5). Additionally, she chastised higher education for not providing an environment that modeled "a more liberal and more accessible work environment for people balancing multiple commitments" (p. 5). She supported her conclusions with stories from faculty and staff who spoke of their fear of speaking out about their disabilities" [191] (p. 12)

When Vance writes about "the disability", Vance means the ability non-normativity of the body, the 'deficiency' of the body that overshadows all other parts of the person's identity. In the book Ableism in Academia [73], various authors reflect on the negative identity experience of disabled people in academia highlighting for example the low disclosure number by people with invisible "disabilities". To provide one quote from the introduction:

"Starting from a very personal experience of disclosing a disability and of dealing with the consequences of that disclosure, Griffiths reflects on how specific forms of knowledge production and particular ways of working are normalized and disability is not considered appropriately" [73] (p. 7)

Many chapters in the book indicate the need to be able to choose the identity of one's body as one sees fit. One study focusing on nursing students with dyslexia found "The majority of students rejected any reference to using medical or disabled discourses and instead drew on contemporary language in constructing their dyslexic identity" [192] (p. 360).

Another example (not university linked) for the negative body identity having a huge impact is revealed by the comments given by disabled people taking part in sustainable development consultations where disabled participants noted that disabled people are mostly excluded from sustainability policy discussions, because their identity is fixed as a deficient one [193-195].

One recognized problem that arises from being identified in a negative way is the evaluation of teachers with a stigmatized identity. Problems with student evaluations of teaching is a recognized problem and it is linked to the identity that one is linked to; to give one quote from a participant:

Students really resisted hearing about Aboriginal [perspectives]. And [instructors] got really poor teaching evaluations from their students. And I know they're good teachers because I've watched them teach and known other classes they've done better. And they're really ridden hard by the students in those settings, to not vary from the norm of what [students] perceive as the conventional type of [content] (Robert) [165] (p. 11)

Regarding student evaluations, another article looking at LGBTQ academics makes the link between teaching evaluation and a stigmatized identity of a teacher:

"Disclosing a stigmatized identity-especially if it intersects with other marginalized identities-may undermine authority in the classroom (Branfman, 2015; Misawa, 2015), leaving faculty 'viewed as biased, politically coercive, inappropriate and non-academic' (Johnson, 2009, p. 186) or seen as pushing an agenda (Nielson \& Anderson, 2014)" [10] (p. 3) (for the references that are cited in the quote [196-199]) 
Given that disability, as in not being ability normative, as in seen as impaired, is a stigmatized identity and it contains a negative default position, one should expect that disabled teachers should experience the same problem, especially if they teach content that does not adhere to the negative identity. In one thesis, such problem is briefly noted [186]. However, no studies cover this topic within the EDI literature, although some say that it should be covered [165].

\subsubsection{Othering Disabled People in EDI}

Narratives around disabled students, non-academic staff, and academic staff impact how they interact and relate to other 'non-deficient groups' and how the other groups relate to them and, as such, impacts the intersectionality aspect of disabled people. Othering based on their identity is described as a problem for disabled people [191], and it is noted that it has an effect disabled faculty experience "that upheld ableist and disablist logics while othering professors' disability identities in the classroom" [200] (p. 118). Othering is also discussed in relation to equity [201], diversity [202-204], and inclusion [205] in the literature. There are signs that disabled people are seen differently in university EDI efforts than other groups, which can influence how and if at all EDI is discussed in relation to disabled people and what is said and not said but could have been said [206-209], and to "other" disabled people at the university. One sign is that the narrative of purpose and focus of a given endeavour is simply different. To give the example of the university of Toronto by giving some quotes of how EDI offices [210] give meaning to three EDI groups:

"The Accessibility for Ontarians with Disabilities Act (AODA) Office ensures that $\mathrm{U}$ of $\mathrm{T}$ is meeting the AODA standard obligations as legislated by the Province of Ontario and makes the university accessible for all staff, faculty, librarians and students. The Office delivers online and in-person training, as well as provides outreach and resources among other support services" [211]

"The Anti-Racism and Cultural Diversity Office (ARCDO) within the Division of Human Resources \& Equity, provides services to support university members in their efforts to foster environments that are intentionally racially diverse and inclusive through the advancement of equitable practices, education and training and the provision of complaints resolution supports on matters of race, faith and intersecting identities as guided by the Ontario Human Rights Commission" [212] and from the "Reflect. Restore. Action" page of the Anti-Racism and Cultural Diversity Office (ARCDO) highlighting a past event "The Anti-Racism \& Cultural Diversity Office joins the university of Toronto in denouncing Anti-Black racism in all its forms. There is no denying the pain, sadness, and anger that many are feeling given recent events of racialized violence. As we navigate, strategize and action-plan during these difficult times, the Anti-Racism and Cultural Diversity Office invite the $\mathrm{U}$ of $\mathrm{T}$ community to join on Thursday, June 4 th for a space of restoration and critical dialogue while building community with colleagues during these challenging times" [213]

“The Sexual \& Gender Diversity Office (SGDO) develops partnerships to build supportive learning and working communities at the university of Toronto by working towards equity and challenging discrimination values. The Sexual \& Gender Diversity Office operates by: Centring principles of equity and intersectionality; Facilitating supportive and inclusive communities within the university; Engaging in ongoing learning, support and advocacy concerning sexual and gender diversity; Connecting the university of Toronto with broader LGBTQ communities; Recognizing our histories and supporting a creative vision for the future" [214]

It is obvious that the webpage content covering disabled people is quite different in tone to the other two groups that we quoted, with the language used to describe the disabled people's office leaving the impression that its really a legal compliance office. 
Why does the university of Toronto EDI disability office highlights that they comply with the AODA (for similar example in other universities see for example $[215,216]$ ) and sees this as their defining characteristic of the EDI office focusing on disabled people? There are more problems for disabled people at the university besides access. It could easily be named "Ability diversity office" similar to the use here: "Community Rehabilitation and Disability Studies Program: Vision: Responsive, sophisticated and just understandings of people of diverse abilities. Mission: Our mission is to generate research, education, policy and practice partnerships to improve well-being of people with diverse abilities" [217]. Using neutral terms, such as "ability diverse" or "ability diversity" fits with the capability approach that perceives "diversity, equity and inclusivity in abilities" [138] (p. 452) as important "to transform means into achievements, it is preferable to views that focus on equality of means. Therefore, CA aims to obtain outcomes that people will value while empowering them" [138] (p. 452). This would allow for a positive self-identity with who one is and fits with that it is argued that "diversity includes important and interrelated dimensions of human identity, such as race, ethnicity, color, gender, socio-economic status, nationality, citizenship, education, geographic origin, religion, sexual orientation, ability, age, political beliefs and or other ideologies" [58]. If EDI is rebranded to be about the acceptance of ability diversity, it would facilitate a refocus on the essential for EDI, which is to engage with what ability expectations are relevant or irrelevant and an engagement with ability privilege. Using ability diversity as a lens also facilitates intersectionality, because disabled people are not the only group that has to deal with which ability expectations are relevant and that are irrelevant ability expectations based on ability privilege. Indeed, the recent disaster that was caused by COVID-19 added to the urgency to discuss ability diversity and what are relevant and irrelevant ability expectations. Wordings, such as Anti-disablism Office (if the word disablism is used to mean discrimination), or even the phrases "Office of disabled people" or "Office for people with disabilities" (if the content of the description uses language around human rights, equity, and intersectionality, whereby accessibility is just one part of the problem and focus), would be better for EDI purposes.

\subsection{Quantity and Diversity of Disabled People}

The failure to differentiate is one of the problems identified in relation to EDI and race [58]. The 'disability' definition is also one glaring example of such a failure to differentiate. The very definition of "impaired person" is very broad. The definitions of "impaired person" used for example in Canadian universities in compliance with the Employment Equity Act covers: acquired brain injury, ADHD, autism spectrum disorder, chronic health disability (e.g., Crohn's disease, hemophilia, epilepsy, asthma, diabetes, HIV / AIDS, cancer, pain, etc.), coordination or dexterity disability (e.g., arthritis, cerebral palsy, cystic fibrosis, multiple sclerosis), deaf, deafened, hard of hearing, learning disability, mental health disability (e.g., schizophrenia, chronic depression, anxiety disorder, bipolar disorder, etc.), mobility disability (e.g., amputations, paraplegia, reliance on a walker, scooter, or mobility aid due to disability), speech impairment (e.g., aphasia, stuttering, cluttering, etc.), vision loss or impairment, and legally blind (not correctable by glasses or contact lenses) (see, for example, $[176,218,219]$ ). However, the data are rarely segregated based on the different "disabilities".

Given this broad definition of 'impaired person', at least 30-40\% of the university population can be defined as "impaired" (given, for example, that $26.3 \%$ of students are seen as having mental health issues [220]). It puts many people together under the deficiency language, not only the ones that do not self-identify as deficient (e.g., deaf culture and neurodiversity), but also so many different ability diversities, all of which pose different EDI implementation challenges. The disabled people that are covered under this definition have vastly different approaches as to their identity, their lived reality, the daily barriers they face, and the attitudes they face.

Given the broad definition of "disability", many target numbers should be revised up; for example, $5.4 \%$ of the total Canada Research Chairs are to be filled with disabled 
faculty [221], which is much too low. According to Statistics Canada, 6.7\% of university professors, instructors, teachers, or researchers have a self-identified disability, which suggests that the vast majority of 'disabilities' are not declared by disabled university professors, instructors, teachers, or researchers. Indeed, given the negative imagery of ability diversity, the lack of ability identity security, and the many negative experiences that are linked to being defined as impaired, it does not seem sensible to self-identify as having a disability if one does not have to do so.

According to Statistics Canada, disabled university professors, instructors, teachers, or researchers are the groups with the highest level of harassment, discrimination, and unfair treatment recorded [100]. However, as bad as these numbers are, they do not tell the whole story, because what the unfair treatment, the discrimination, and the harassment was very likely different based on the persons 'impairment' and remedies and training of others to deal with the problem would have to be quite different, based on the 'impairment'. Indeed, anti-harassment and anti-bullying modules used in many universities housed under Occupational Health and Safety do not also have to cover disabled people in general, but such coverage must be differentiated based on the ability difference. Some harassments and bullying actions might be experienced the same by all disabled academic staff, but many, such as language, use linked microaggression is different for different groups of disabled people.

\subsection{EDI, Disabled People, and Broader Science Recommendations}

Improvement in how research is done and what is researched is one main focus of EDI $[1,24,32,222,223]$; for example, EDI is employed to enable to "drive deeper cultural change within the research ecosystem" [46] and EDI efforts are linked to various international documents covering how to do science, such as the 2017 "UNESCO Recommendation on Science and Scientific Researchers [40] and the UNESCO World Conference on Sciences 1999 conference documents [29,30].

The 2017 "UNESCO Recommendation on Science and Scientific Researchers demands "equitable conditions of work, recruitment and promotion, appraisal, training and pay without discrimination" based on ... disability" [40]. This aligns with the EDI mandate and EDI could be used to strengthen the recommendations. The problem is how to implement this and what this quote exactly includes. Does implementing this demand include that one can work on the social topics of relevance to disabled people? Does implementing this demand include funders providing as much funding for projects covering the "social" of disabled people than for projects covering the "medical"? How these two questions are answered will influence the relationship between EDI and the UNESCO recommendation. If the two questions answered with a yes, that suggests an added facet to the EDI and disabled people at university, which is not really discussed so far.

This study showed that the EDI has a bias toward seeing disabled people in certain ways, and the academic coverage of EDI shows a bias against covering disabled people as part of EDI. Therefore, the EDI discourse in the moment does not lead to the elimination of bias against disabled people, which is mentioned as a goal in Section 3, 13(c) of the 2017 "UNESCO Recommendation on Science and Scientific Researchers: "in order to remediate past inequalities and patterns of exclusion, actively encourage women and persons of other under-represented groups to consider careers in sciences and endeavour to eliminate biases against women and persons of other under-represented groups in work environments and appraisal" [40] (p. 120). In the 2017 "Recommendation on Science and Scientific Researchers" [40], the following is stated: "the word "science" signifies the enterprise, whereby humankind, acting individually or in small or large groups, makes an organized attempt, by means of the objective study of observed phenomena and its validation through sharing of findings and data" [40] (p. 120). This quote raises the question of what "objective" means for disabled people, including researchers that want to work on a non-medical narrative of disabled people given the medical and ability bias in evidence? The wording suggests a vast task to unravel conscious and unconscious ability 
biases and ability privilege biases and blind spots in academia and elsewhere. Others have argued that the 2017 "UNESCO Recommendation on Science and Scientific Researchers will transform working conditions, rights and responsibilities of researchers globally" [164]. However, based on the findings of this study, EDI's engagement with disabled people must substantially change in relation to disabled people to make that statement true.

The UNESCO World Conference on Sciences 1999 conference $[29,30]$ acknowledged, in point 25 and 42, barriers that disabled people and other groups face in relation to science and being scientists [29]. As such, one could have acted upon these documents since 1999, and EDI for disabled people could now act on these documents. The documents demand including disabled people into scientific networks (point 17, [30]), in all aspects of research activities, including the development of policies (point 79, [30]), and demand identification and elimination of discriminatory educational practices to enable participation in science of disabled people (point 81, [30]). Point 91 gives the explicit action items to ensure the full participation of disadvantaged groups (including disabled people in the definition point 25 [29]) in science and technology, namely: removing barriers in the education system; removing barriers in the research system; raising awareness of the contribution of these groups to science and technology in order to overcome existing stereotypes; undertaking research, supported by the collection of data, documenting constraints; monitoring implementation and documenting best practices; and, ensuring representation in policy-making bodies and forums [30]. Given the findings around the lack of EDI focused academic engagement with disabled people, one can conclude that the EDI system falls short of all the demands made in the 1999 documents.

\section{Conclusions and Future Research}

This study indicates a lack of academic engagement with EDI as it relates to disabled students, non-academic, and academic staff. This is troubling, but also an opportunity. Given that disabled students, non-academic, and academic staff encounter severe problems and barriers in post-secondary education, including in relation to their identity $[25-28,68,70-75,79,82-90,93-98,149-157,224-226]$, given that policies are to be informed by evidence and that policies can influence what is researched [39,158-163], given the nearly total lack of engagement with undergraduate disabled students as researchers and how to build the academic pipeline for disabled faculty [26], and given the lack of evidence around the social situation of disabled people [35-39], studies providing the data that are needed to make EDI a success for disabled students, non-academic staff, and academic staff are warranted. Indeed, given the mentioning of disabled people in various sections, for example, in the report "Igniting Change: Final Report and Recommendations" by the Congress Advisory Committee on Equity, Diversity, Inclusion, and Decolonization (AC-EDID) [227].

Given that EDI articles covering other EDI groups indicate the importance of one's identity [188], studies are needed that investigate, in detail, the impact of how disabled people are labelled in EDI discourses and the consequences of not experiencing ability identity security (to be able to be at ease with ones set of abilities) [112]. Given the breadth of what falls under the definition of disabled people in EDI, one must revisit whether the EDI targets for disabled students, non-academic staff, and academic staff are too low. EDI data are also needed on the different 'deficiencies', as the people exhibiting the different 'deficiencies' have totally different views and lived experience.

Research into the impact of EDI on the social situation of disabled people and how to measure it is also warranted given that policies are to be informed by evidence and research is warranted on why EDI efforts have not led so far to the closing of the evidence gap on the social situation of disabled people.

EDI research must address that $35 \%$ of disabled university professors, instructors, teachers, or researchers at Canadian universities "experienced unfair treatment or discrimination in the past 12 months and $47 \%$ saw themselves subjected to at least one type of 
harassment in the past 12 month" [100]. Whereby, they were the group with the highest number (assuming that these high numbers are not a Canadian exclusive phenomenon).

Regarding EDI literacy and EDI education, disabled people outlined, in online fora covering the 2030 sustainable development goals, many roles and actions that universities and their faculty should take in relation to disabled people and their situation. Many of these could be looked at through an EDI lens [193-195,228,229]. One can investigate how curricula cover EDI, especially in relation to disabled students, non-academic staff, and academic staff.

Given the example of language highlighted earlier around EDI offices at the university of Toronto, one can investigate the language of how university webpages and documents deal with the different EDI groups and compare the language used for disabled students, non-academic staff, and academic staff and other EDI groups.

A 2020 Master thesis states that "Social workers and social work faculty have a "natural inclination towards inclusion, equity and diversity" [186] (p. 35), suggesting that one could have a look at other social work faculties and how they deal with the different EDI groups, such as disabled people. Additionally, of course, such studies can be performed with every faculty. There are a few theses covering disabled faculty [230-233] and disability microaggression $[185,186]$, whose findings suggest various possibilities for follow up EDI research.

It is argued that equity diversity and inclusion are concepts that should be present in high schools [234], and literature around women and STEM indicate that one must go to school to initiate change. Accordingly, to fill the pipeline of women going into STEM fields in universities and fill faculty positions, it seems logical to suggest that EDI engagement with disabled people has to start in schools [26]. A recent thesis looked at some high school districts in the USA and how they use EDI [234]. Such investigation can be applied to other school districts. If school students learn about EDI, they are already sensitized to look at their university life through EDI, which might decrease many of the problems that disabled students at universities face that are caused by fellow students.

Finally, there are various tools that can help EDI endeavours to make visible the problems disabled people and other EDI linked groups face. A recent workshop that focused on diversity, equity, inclusion, and implicit bias in academia focusing on race and ethnicity [58] could be modified to cover ability diversity, ability privilege, and ability bias. Various ability expectation exercises $[184,235]$ could be used to reveal unconscious ability biases and ability privilege biases. The BIAS Free (Building an Integrative Analytical System For Recognizing and Eliminating inEquities) framework $[236,237]$ is a tool that was developed for identifying biases that derive from social hierarchies, including disabled people and abilities. The BIAS Free poses 20 questions that indicate biases that help to maintain hierarchies in three main sections: H-Maintaining an Existing Hierarchy; F-Failing to Examine Differences; and, D-Using Double Standards. As such, it is a useful tool to make people realize the existence of ability based and other biases within themselves and others. It can be used to analyse data and find real life examples for the biases in relation to disabled people and others.

Author Contributions: Conceptualization, G.W.; methodology, G.W.; formal analysis, G.W. and A.L.; investigation, G.W. and A.L.; data curation, G.W. and A.L.; writing-original draft preparation, G.W. and A.L.; writing-review and editing, G.W. and A.L.; supervision, G.W.; project administration, G.W.; funding acquisition, G.W. All authors have read and agreed to the published version of the manuscript.

Funding: This research was funded by the Government of Canada, Canadian Institutes of Health Research, Institute of Neurosciences, Mental Health and Addiction ERN 155204 in cooperation with ERA-NET NEURON JTC 2017.

Institutional Review Board Statement: Not applicable.

Informed Consent Statement: Not applicable. 


\section{Data Availability Statement: Not applicable.}

Conflicts of Interest: The authors declare no conflict of interest.

\section{References}

1. Advance HE. Athena Swan Charter Encouraging and Recognising Commitment to Advancing Gender Equality. Available online: https:/ / www.advance-he.ac.uk/equality-charters/athena-swan-charter (accessed on 20 April 2021).

2. Advance HE. Race Equality Charter. Available online: https://www.advance-he.ac.uk/equality-charters (accessed on 20 April 2021).

3. Advance HE. Disabled People. Available online: https://www.advance-he.ac.uk/guidance/equality-diversity-and-inclusion/ creating-inclusive-environment/disabled-people (accessed on 20 April 2021).

4. Fuentes, M.A.; Zelaya, D.G.; Madsen, J.W. Rethinking the Course Syllabus: Considerations for Promoting Equity, Diversity, and Inclusion. Teach. Psychol. 2021, 48, 69-79. [CrossRef]

5. Gregory, R. Promoting Equity, Diversity, Inclusion, and Wellness in Faculty Hiring. Available online: https://www.uoguelph.ca/ $\mathrm{ib} /$ system/files/IB_EDI\%20Hiring\%20Strategies_July2020.pdf (accessed on 20 April 2021).

6. MacGregor, S. Perseverance and Higher Education in Canada. Can. J. New Sch. Educ. Rev. Can. Jeunes Cherch. Cherch. Educ. 2020, $11,1-2$.

7. Wright, E.; Cukier, W. Assessing Diversity and Inclusion within Canadian Universities. Available online: https://www.westmont. edu/sites/default/files/users/user551/Wright\%20et\%20al.pdf (accessed on 20 April 2021).

8. Ruel, S.; Tajmel, T. Equity, Diversity, and Inclusivity at the Intersection of STEM and Business Management in Canadian Higher Education. Available online: https:/ / www.cfbsd.ca/resources/Documents / Final\%20Report\%20-\%20EDI\%20in\%20STEM\%20 and\%20Business\%20Management\%20(1).pdf (accessed on 20 April 2021).

9. Mianda, G. Behind Diversity and Inclusive Politics: A Reading from a Francophone Scholar at the Margin of the Canadian Academy. Can. Rev. Sociol. Can. Sociol. 2020, 57, 480-483. [CrossRef] [PubMed]

10. Beagan, B.L.; Mohamed, T.; Brooks, K.; Waterfield, B.; Weinberg, M. Microaggressions experienced by LGBTQ academics in Canada: "just not fitting in ... it does take a toll". Int. J. Qual. Stud. Educ. 2021, 34, 197-212. [CrossRef]

11. Ile, P. Disability through My Lens: The Experiences of Inclusion and Belonging of Students with Disabilities at SFU. Available online: http:/ / dspace.library.uvic.ca/bitstream/handle/1828/11966/Ile_Precious\%20_MACD_2020.pdf?sequence=1\&isAllowed=y (accessed on 20 April 2021).

12. European University Association. Diversity, Equity and Inclusion in European Higher Education Institutions Results from the INVITED Project. Available online: https:/ / eua.eu/downloads/publications/web_diversity $\% 20$ equity $\% 20$ and $\% 20$ inclusion $\% 20$ in\%20european\%20higher\%20education\%20institutions.pdf (accessed on 20 April 2021).

13. Irish Universities Association. Equality, Diversity and Inclusion. Available online: https://www.iua.ie/ourwork/diversityequality/ (accessed on 20 April 2021).

14. The Unversity of Edinburgh School of Physics and Astronomy. What Does Equality, Diversity, and Inclusion Mean? Available online: https: / / www.ph.ed.ac.uk/equality-diversity-and-inclusion/about-edi/what-does-equality-diversity-and-inclusionmean (accessed on 20 April 2021).

15. Advance HE (UK). Equality, Diversity and Inclusion. Available online: https://www.advance-he.ac.uk/guidance/equalitydiversity-and-inclusion (accessed on 20 April 2021).

16. Universities, U. Equality, Diversity and Inclusion. Available online: https://www.universitiesuk.ac.uk/policy-and-analysis/ Pages/equality-diversity-inclusion.aspx (accessed on 20 April 2021).

17. University College London (UCL). Equity and Inclusion Plan 2020-2021. Available online: https://www.ucl.ac.uk/equalitydiversity-inclusion/equalityucl/new-ucl-plan-launched-ensure-momentum-equity-and-inclusion/equity-and-inclusion-plan (accessed on 20 April 2021).

18. University College London (UCL). Equality, Diversity and Inclusion. Available online: https://www.ucl.ac.uk/equality-diversityinclusion/ (accessed on 20 April 2021).

19. Tamtik, M.; Guenter, M. Policy Analysis of Equity, Diversity and Inclusion Strategies in Canadian Universities-How Far Have We Come? Can. J. High. Educ. Rev. Can. Enseign. Supérieur 2019, 49, 41-56. [CrossRef]

20. Worthington, R.L.; Stanley, C.A.; Lewis, W.T., Sr. Advancing the professionalization of diversity officers in higher education: Report of the Presidential Task Force on the Revision of the NADOHE standards of professional practice. J. Divers. High. Educ. 2014, 13, 1-22. [CrossRef]

21. Chavez-Haroldson, M.T. LatinX Diversity Officers in Higher Education: Capacitating Cultural Values as Champions of Equity, Diversity, and Inclusion. Available online: https:/ / aura.antioch.edu/etds/551/ (accessed on 20 April 2021).

22. Mellifont, D.; Smith-Merry, J.; Dickinson, H.; Llewellyn, G.; Clifton, S.; Ragen, J.; Raffaele, M.; Williamson, P. The ableism elephant in the academy: A study examining academia as informed by Australian scholars with lived experience. Disabil. Soc. 2019, 34, 1180-1199. [CrossRef]

23. Mellifont, D. A critical exploration of university policy supporting the employment and career development of people with disability in the Australian academy. Aust. J. Career Dev. 2020, 29, 117-126. [CrossRef]

24. Government of Canada. Dimensions: Equity, Diversity and Inclusion Canada. Available online: http://www.nserc-crsng.gc.ca/ NSERC-CRSNG/EDI-EDI/Dimensions-Charter_Dimensions-Charte_eng.asp (accessed on 20 April 2021). 
25. Wolbring, G. Special Educational Needs and Disabilities in Higher Education (Canada). Bloomsbury Educ. Child. Stud. 2019. [CrossRef]

26. Lillywhite, A.; Wolbring, G. Undergraduate Disabled Students as Knowledge Producers including Researchers: A Missed Topic in Academic Literature. Educ. Sci. 2019, 9, 259. [CrossRef]

27. Saltes, N. Disability Barriers in Academia: An Analysis of Disability Accommodation Policies for Faculty at Canadian Universities. Can. J. Disabil. Stud. 2020, 9, 53-90. [CrossRef]

28. Prema, D.; Dhand, R. Inclusion and accessibility in STEM education: Navigating the duty to accommodate and disability rights. Can. J. Disabil. Stud. 2019, 8, 121-141. [CrossRef]

29. UNESCO. UNESCO World Conference on Sciences Declaration on Science and the Use of Scientific Knowledge. Available online: http://www.unesco.org/science/wcs/eng/declaration_e.htm (accessed on 20 April 2021).

30. UNESCO. UNESCO World Conference on Sciences, Science Agenda-Framework for Action. Available online: http://www. unesco.org/science/wcs/eng/framework.htm (accessed on 20 April 2021).

31. Natural Sciences and Engineering Research Council of Canada. 2019 Made-In-Canada Athena SWAN Consultations. Available online: http:/ / www.nserc-crsng.gc.ca/Forms-formulaires/Swan-2019_eng.asp (accessed on 20 April 2021).

32. Government of Canada. Canada Research Chairs Equity, Diversity and Inclusion Requirements and Practices. Available online: http:/ / www.chairs-chaires.gc.ca/program-programme/equity-equite/index-eng.aspx (accessed on 20 April 2021).

33. Government of Canada. Advisory Committee on Equity, Diversity and Inclusion Policy. Available online: http://www.chairschaires.gc.ca/program-programme/equity-equite/advisory_committee_on_equity-eng.aspx (accessed on 20 April 2021).

34. United Nations. Convention on the Rights of Persons with Disabilities (CRPD). Available online: https://www.un.org/ development/desa/disabilities/convention-on-the-rights-of-persons-with-disabilities.html (accessed on 20 April 2021).

35. Chataika, T.; McKenzie, J.A. Global institutions and their engagement with disability mainstreaming in the south: Development and (dis) connections. In Disability in the Global South. International Perspectives on Social Policy, Administration, and Practice; Grech, S., Soldatic, K., Eds.; Springer: Berlin/Heidelberg, Germany, 2016; pp. 423-436.

36. World Health Organization. World Report on Disability. Available online: http://www.who.int/disabilities/world_report/2011 /en/index.html (accessed on 20 April 2021).

37. Berghs, M.; Atkin, K.; Graham, H.; Hatton, C.; Thomas, C. Implications for public health research of models and theories of disability: A scoping study and evidence synthesis. Public Health Res. 2016, 4, 1-166. [CrossRef]

38. Wolbring, G.; Djebrouni, M.; Johnson, M.; Diep, L.; Guzman, G. The Utility of the "Community Scholar" Identity from the Perspective of Students from one Community Rehabilitation and Disability Studies Program. Interdiscip. Perspect. Equal. Divers. 2018, 4. Available online: http://journals.hw.ac.uk/index.php/IPED/article/view/53/481-28 (accessed on 20 April 2021).

39. Wolbring, G.; Djebrouni, M. Motivated Reasoning and Disabled People. Interdiscip. Perspect. Equal. Divers. 2018, 4. Available online: http:/ /journals.hw.ac.uk/index.php/IPED/article/view/61/47 (accessed on 20 April 2021).

40. United Nations General Conference 39th Session. ANNEX II Recommendation on Science and Scientific Researchers. Available online: https:/ / unesdoc.unesco.org/ark:/48223/pf0000260889 (accessed on 20 April 2021).

41. Advance HE. International Charters. Available online: https://www.advance-he.ac.uk/equality-charters/international-charters (accessed on 20 April 2021).

42. Royal Commission on Equality in Employment. Equality in Employment Report. Available online: http:/ / equalpaycoalition.org/ wp-content/uploads/2017/07/Equality-in-Employment-A-Royal-Commission-Report-Abella-Complete-Report.pdf (accessed on 20 April 2021).

43. Henry, F.; Dua, E.; Kobayashi, A.; James, C.; Li, P.; Ramos, H.; Smith, M.S. Race, racialization and Indigeneity in Canadian universities. Race Ethn. Educ. 2016, 20, 300-314. [CrossRef]

44. Universities Canada. Universities Canada Principles on Equity, Diversity and Inclusion. Available online: https://www.univcan. $\mathrm{ca} /$ media-room/media-releases/universities-canada-principles-equity-diversity-inclusion/ (accessed on 20 April 2021).

45. Government of Canada. Best Practices in Equity, Diversity and Inclusion in Research: A guide for Applicants to New Frontiers in Research Fund Competitions. Available online: https://www.sshrc-crsh.gc.ca/funding-financement/nfrf-fnfr/edi-eng.aspx (accessed on 20 April 2021).

46. Government of Canada. Equity, Diversity and Inclusion: Dimensions. Available online: https://www.nserc-crsng.gc.ca/NSERCCRSNG/EDI-EDI/Dimensions_Dimensions_eng.asp (accessed on 20 April 2021).

47. Government of Canada. Equity, Diversity and Inclusion: Dimensions: Charter. Available online: https://www.nserc-crsng.gc.ca/ NSERC-CRSNG/EDI-EDI/Dimensions-Charter_Dimensions-Charte_eng.asp (accessed on 20 April 2021).

48. Alfred, M.V.; Ray, S.M.; Johnson, M.A. Advancing Women of Color in STEM: An Imperative for U.S. Global Competitiveness. Adv. Dev. Hum. Resour. 2019, 21, 114-132. [CrossRef]

49. Bilimoria, D.; Singer, L.T. Institutions Developing Excellence in Academic Leadership (IDEAL). Equal. Divers. Incl. Int. J. 2019, 38, 362-381. [CrossRef]

50. Chaudhary, V.B.; Berhe, A.A. Ten simple rules for building an antiracist lab. PLoS Comput. Biol. 2020, 16, e1008210. [CrossRef]

51. Handley, H.K.; Hillman, J.; Finch, M.; Ubide, T.; Kachovich, S.; McLaren, S.; Petts, A.; Purandare, J.; Foote, A.; Tiddy, C. In Australasia, gender is still on the agenda in geosciences. Adv. Geosci. 2020, 53, 205-226. [CrossRef]

52. Weissmann, G.S.; Ibarra, R.A.; Howland-Davis, M.; Lammey, M.V. The multicontext path to redefining how we access and think about diversity, equity, and inclusion in STEM. J. Geosci. Educ. 2019, 67, 320-329. [CrossRef] 
53. Yen, J.; Riskin, E.A.; Margherio, C.; Spyridakis, J.H.; Carrigan, C.M.; Cauce, A.M. Promoting gender diversity in STEM faculty through leadership development. Equal. Divers. Incl. Int. J. 2019, 38, 382-398. [CrossRef]

54. Bierema, L.L. Ladies and gentlemen, your implicit bias is showing: Gender hegemony and its impact on HRD research and practice. Hum. Resour. Dev. Int. 2020, 23, 1-18. [CrossRef]

55. Willis, L.M.; Mehta, D.; Davis, A. Twelve Principles Trainees, PIs, Departments, and Faculties Can Use to Reduce Bias and Discrimination in STEM. ACS Cent. Sci. 2020, 6, 2294-2300. [CrossRef]

56. Whatley, M.H. A feeling for science: Female students and biology texts. Women's Stud. Int. Forum 1989, 12, 355-361. [CrossRef]

57. Cameron, P.; LeBlanc, C.; MacLeod, A.; MacLeod, T.; O’Hearn, S.; Simpson, C. Women leaders' career advancement in academic medicine: A feminist critical discourse analysis. In Handbook on Promoting Social Justice in Education; Papa, R., Ed.; Springer: Berlin/Heidelberg, Germany, 2020; pp. 1779-1803.

58. Harrison-Bernard, L.M.; Augustus-Wallace, A.C.; Souza-Smith, F.M.; Tsien, F.; Casey, G.P.; Gunaldo, T.P. Knowledge gains in a professional development workshop on diversity, equity, inclusion, and implicit bias in academia. Adv. Physiol. Educ. 2020, 44, 286-294. [CrossRef]

59. Helitzer, D.L.; Newbill, S.L.; Cardinali, G.; Morahan, P.S.; Chang, S.; Magrane, D. Narratives of Participants in National Career Development Programs for Women in Academic Medicine: Identifying the Opportunities for Strategic Investment. J. Women's Health 2016, 25, 360-370. [CrossRef]

60. Spafford, M.M.; Nygaard, V.L.; Gregor, F.; Boyd, M.A. “Navigating the Different Spaces”: Experiences of Inclusion and Isolation Among Racially Minoritized Faculty in Canada. Can. J. High. Educ. 2006, 36, 01-27. [CrossRef]

61. Government of Canada. Employment Equity Act (S.C. 1995, c. 44). Available online: https://laws-lois.justice.gc.ca/PDF/E-5.401. pdf (accessed on 20 April 2021).

62. Statistics Canada. Table 37-10-0165-01 Selected Population Characteristics of Postsecondary Faculty and Researchers by Region, Role, and Employment Status. Available online: https:/ / www150.statcan.gc.ca/t1/tbl1/en/tv.action?pid=3710016501 (accessed on 20 April 2021).

63. University or Reading. Who is the Disability Advisory Service for? Available online: https://www.reading.ac.uk/essentials/ support-and-wellbeing/disability/what-counts-as-a-disability (accessed on 20 April 2021).

64. HM Government. Equality Act 2010 Guidance. Available online: https://assets.publishing.service.gov.uk/government/uploads/ system/uploads/attachment_data/file/570382/Equality_Act_2010-disability_definition.pdf (accessed on 20 April 2021).

65. University of Cambridge. Disability Resource Centre. Available online: https://www.disability.admin.cam.ac.uk/thinkingabout-disability / law-and-higher-education-sector-guidance\#: \{\}:text=Definition \%20of\%20disability \%20under\%20the \%20 Equality\%20Act\&text=A\%20person\%20has\%20a\%20disability,Act\%202010\%2C\%20Section\%206). (accessed on 20 April 2021).

66. The University of Auckland. Students with Disabilities Disclosure Guidelines. Available online: https://www.auckland.ac.nz/ en/about/the-university/how-university-works/policy-and-administration/equity/students-with-disabilities-disclosureguidelines.html\#: \{\}:text=The\%20New\%20Zealand\%20Disability\%20Strategy,disabled \%20people \%20have \%20in \%20common (accessed on 20 April 2021).

67. Curtin University. What Is a Disability? Available online: https://students.curtin.edu.au/personal-support/disability/ definition/\#: \{\}:text=The\%20Australian\%20Government $\backslash$ T1 $\backslash$ textquoterights\%20Disability\%20Discrimination, a $\% 20$ part $\%$ 20of $\%$ 20the \%20body\&text=A\%20disorder\%20or\%20malfunction \%20that, without $\% 20$ the \%20disorder\%20or\%20malfunction (accessed on 20 April 2021).

68. Devlin, R.; Pothier, D. Introduction: Toward a critical theory of dis-citizenship. In Critical Disability Theory: Essays in Philosophy, Politics, Policy, and Law; Devlin, R., Pothier, D., Eds.; UBC Press: Vancouver, QC, Canada, 2006; pp. 1-22.

69. Moriña, A.; Carnerero, F. Conceptions of Disability at Education: A Systematic Review. Int. J. Disabil. Dev. Educ. 2020, 1-15. [CrossRef]

70. Kraus, A. The Sociopolitical Construction of Identity: A Multidimensional Model of Disability. Available online: https://arizona. openrepository.com/bitstream/handle/10150/193722/azu_etd_2625_sip1_m.pdf?sequence=1 (accessed on 20 April 2021).

71. Hutcheon, E.; Wolbring, G. Voices of disabled post secondary students: Examining higher education disability policy using an ableism lens. J. Divers. High. Educ. 2012, 5, 39-49. [CrossRef]

72. Brown, N.; Leigh, J. Ableism in academia: Where are the disabled and ill academics? Disabil. Soc. 2018, 33, 985-989. [CrossRef]

73. Various. Ableism in Academia Theorising Experiences of Disabilities and Chronic Illnesses in Higher Education; Brown, N., Leigh, J., Eds.; UCL Press London and Online Open Access: London, UK, 2020.

74. Government of Canada. 2010 Federal Disability Report-Chapter 3: Learning. Available online: https://www.canada.ca/en/ employment-social-development/programs/disability/arc/federal-report2010/chapter3.html (accessed on 20 April 2021).

75. Government of Canada. A Profile of Persons with Disabilities among Canadians Aged 15 Years or Older. 2012. Available online: https:/ / www150.statcan.gc.ca/n1/pub/89-654-x/89-654-x2015001-eng.htm (accessed on 20 April 2021).

76. Dali, K. The lifeways we avoid. J. Doc. 2018, 74, 1258-1273. [CrossRef]

77. Schneider, J.; Dutton, J. Attitudes towards Disabled Staff and the Effect of the National Minimum Wage: A Delphi survey of employers and disability employment advisors. Disabil. Soc. 2002, 17, 283-306. [CrossRef]

78. Gilson, C.; Dymond, S. Constructions of Disability at a University in Hong Kong: Perspectives of Disabled Students, Staff Members, and Instructors. Disabil. Stud. Q. 2011, 31. [CrossRef]

79. Lourens, H. Supercripping the academy: The difference narrative of a disabled academic. Disabil. Soc. 2020, 1-16. [CrossRef] 
80. Vergunst, R.; Swartz, L. 'He doesn't understand that he's struggling with the way I felt'-university students, psychosocial disability and disclosure in the Western Cape, South Africa. Disabil. Soc. 2021, 36, 226-239. [CrossRef]

81. Ahmed, N. Can we perform like "super-cripples" during this challenging pandemic? Opportunities for disabled people working in academia. Alter 2020, 14, 247-248. [CrossRef]

82. Olsen, J.; Griffiths, M.; Soorenian, A.; Porter, R. Reporting from the Margins: Disabled Academics Reflections on Higher Education. Scand. J. Disabil. Res. 2020, 22, 265-274. [CrossRef]

83. Gillberg, C. The significance of crashing past gatekeepers of knowledge: Towards full participation of disabled scholars in ableist academic structures. In Ableism in Academia: Theorising Experiences of Disabilities and Chronic Illnesses in Higher Education; Brown, N., Leigh, J., Eds.; UCI Press: London, UK, 2020.

84. Ontario Human Rights Commission. Accessible Education for Students with Disabilities. Available online: http://www.ohrc.on. $\mathrm{ca} /$ sites / default/files/Policy\%20on\%20accessible\%20education\%20for\%20students\%20with\%20disabilities_FINAL_EN.pdf (accessed on 20 April 2021).

85. Canadian Human Rights Commission. Left Out: Challenges Faced by Persons with Disabilities in Canada's Schools. Available online: https:/ / www.chrc-ccdp.gc.ca/sites/default/files/challenges_disabilities_schools_eng.pdf (accessed on 20 April 2021).

86. Olney, M.F.; Kim, A. Beyond Adjustment: Integration of cognitive disability into identity. Disabil. Soc. 2001, 16, 563-583. [CrossRef]

87. Holloway, S. The Experience of Higher Education from the Perspective of Disabled Students. Disabil. Soc. 2001, 16, 597-615. [CrossRef]

88. Low, J. Negotiating Identities, Negotiating Environments: An interpretation of the experiences of students with disabilities. Disabil. Soc. 1996, 11, 235-248. [CrossRef]

89. Barnar-Brak, L.; Lectenberger, D.; Lan, W.Y. Accommodation strategies of college students with disabilities. Qual. Rep. 2010, $15,411-429$.

90. Komesaroff, L. Category politics: Deaf students' inclusion in the 'hearing university'. Int. J. Incl. Educ. 2005, 9, 389-403. [CrossRef]

91. Stentiford, L.; Koutsouris, G. What are inclusive pedagogies in higher education? A systematic scoping review. Stud. High. Educ. 2020, 1-17. [CrossRef]

92. National Educational Association of Disabled Students (NEADS). Comparison of Specific Populations of Graduate Students with Disabilities Using 2016 CGPSS Data. Available online: https://www.neads.ca/en/about/media/CombinedReport_Nov28.pdf (accessed on 20 April 2021).

93. Williams, J.; Mavin, S. Impairment effects as a career boundary: A case study of disabled academics. Stud. High. Educ. 2013, 40, 123-141. [CrossRef]

94. Waterfield, B.; Beagan, B.B.; Weinberg, M. Disabled academics: A case study in Canadian universities. Disabil. Soc. 2018, 33, 327-348. [CrossRef]

95. Corlett, S.; Williams, J. The Effects of Discourse and Local Organizing Practices on Disabled Academics Identities. Available online: https: / / pdfs.semanticscholar.org/20bf/6f07de3da23cc974e86ddfc68937e97741d8.pdf?_ga=2.50989677.574596933.16061 80758-2110569646.1604785950 (accessed on 20 April 2021).

96. Inckle, K. Unreasonable adjustments: The additional unpaid labour of academics with disabilities. Disabil. Soc. 2018, 33, 1372-1376. [CrossRef]

97. Bhakta, A. “Which door should I go through?" (In)visible intersections of race and disability in the academy. Area 2020, 52, 687-694. [CrossRef]

98. Hiscock, J.; Leigh, J. Exploring perceptions of and supporting dyslexia in teachers in higher education in STEM. Innov. Educ. Teach. Int. 2020, 57, 714-723. [CrossRef]

99. Seale, J. From the voice of a 'socratic gadfly': A call for more academic activism in the researching of disability in postsecondary education. Eur. J. Spec. Needs Educ. 2016, 32, 153-169. [CrossRef]

100. Statistics Canada. Table 37-10-0169-01 Unfair Treatment, Discrimination or Harassment among Postsecondary Faculty and Researchers. Available online: https:/ /www150.statcan.gc.ca/t1/tbl1/en/tv.action?pid=3710016901 (accessed on 20 April 2021).

101. Yell, M.L.; Katsiyannis, A.; Rose, C.A.; Houchins, D.E. Bullying and harassment of students with disabilities in schools: Legal considerations and policy formation. Remedial Spec. Educ. 2016, 37, 274-284. [CrossRef]

102. Naezer, M.; Brink, M.v.D.; Benschop, Y. Harassment in Dutch Academia Exploring Manifestations, Facilitating Factors, Effects and Solutions. Available online: https://www.lnvh.nl/uploads/moxiemanager/LNVH_rapport_lsquo_Harassment_in_Dutch_ academia_Exploring_manifestations_facilitating_factors_effects_and_solutions_rsquo_.pdf (accessed on 20 April 2021).

103. Careers Research \& Advisory Centre (CRAC). Qualitative Research on Barriers to Progression of Disabled Scientists. Available online: https: / royalsociety.org/-/media/policy/topics/diversity-in-science/qualitative-research-on-barriers-to-progressionof-disabled-scientists.pdf (accessed on 20 April 2021).

104. Wolbring, G. Why NBIC? Why human performance enhancement? Innov. Eur. J. Soc. Sci. Res. 2008, 21, 25-40. [CrossRef]

105. Wolbring, G. Ability Expectation and Ableism Glossary. Available online: https://wolbring.wordpress.com/abilityexpectationableism-glossary/ (accessed on 20 April 2021).

106. Wolbring, G. Ability Expectation and Ableism Literature. Available online: https://wolbring.wordpress.com/abilityexpectationableism-literature/ (accessed on 20 April 2021).

107. Albrecht, G.L. Encyclopedia of Disability; SAGE Publications: Newbury Park, CA, USA, 2006. 
108. Wolbring, G. Ability Privilege: A needed addition to privilege studies. J. Crit. Anim. Stud. 2014, 12, 118-141.

109. Miller, P.; Parker, S.; Gillinson, S. Disablism How to Tackle the Last Prejudice. Available online: http://www.demos.co.uk/files/ disablism.pdf (accessed on 20 April 2021).

110. Dirth, T.P.; Branscombe, N.R. Recognizing Ableism: A Social Identity Analysis of Disabled People Perceiving Discrimination as Illegitimate. J. Soc. Issues 2019, 75, 786-813. [CrossRef]

111. Wolbring, G.; Yumakulov, S. Education through an Ability Studies Lens. Z. Inkl. 2015, 10. Available online: https://www. inklusion-online.net/index.php/inklusion-online/article/view/278 (accessed on 20 April 2021).

112. Wolbring, G. Ableism and favoritism for abilities governance, ethics and studies: New tools for nanoscale and nanoscale enabled science and technology governance. In The Yearbook of Nanotechnology in Society, Volume II: The Challenges of Equity and Equality; Cozzens, S., Wetmore, J.M., Eds.; Springer: New York, NY, USA, 2010.

113. Hogg, M.A.; Terry, D.J.; White, K.M. A Tale of Two Theories: A Critical Comparison of Identity Theory with Social Identity Theory. Soc. Psychol. Q. 1995, 58, 255. [CrossRef]

114. Burke, P.J.; Reitzes, D.C. An Identity Theory Approach to Commitment. Soc. Psychol. Q. 1991, 54, 239. [CrossRef]

115. Michalko, R.; Titchkosky, T. Rethinking Normalcy: A Disability Studies Reader; Canadian Scholars' Press: Toronto, ON, Canada, 2009.

116. Rosqvist, H.B.; Chown, N.; Stenning, A. Neurodiversity Studies: A New Critical Paradigm; Routledge: London, UK, 2020.

117. Iqtadar, S.; Hernández-Saca, D.I.; Ellison, S. "If It Wasn't My Race, It Was Other Things Like Being a Woman, or My Disability": A Qualitative Research Synthesis of Disability Research. Disabil. Stud. Q. 2020, 40, 40. [CrossRef]

118. Titsworth, B.S. An Ideological Basis for Definition in Public Argument: A Case Study of the Individuals with Disabilities in Education Act. Argum. Advocacy 1999, 35, 171-184. [CrossRef]

119. Maturo, A. The medicalization of education: ADHD, human enhancement and academic performance. Ital. J. Sociol. Educ. 2013, $5,175-188$.

120. Varul, M.Z. Talcott Parsons, the Sick Role and Chronic Illness. Body Soc. 2010, 16, 72-94. [CrossRef]

121. Wilson, R. The Discursive Construction of Elderly's Needs-A Critical Discourse Analysis of Political Discussions in Sweden. Available online: http:/ / www.diva-portal.org/smash/get/diva2:1339948/FULLTEXT01.pdf (accessed on 20 April 2021).

122. Schulz, H.M. Reference group influence in consumer role rehearsal narratives. Qual. Mark. Res. Int. J. 2015, 18, 210-229. [CrossRef]

123. Grant, M.J.; Booth, A. A typology of reviews: An analysis of 14 review types and associated methodologies. Health Inf. Libr. J. 2009, 26, 91-108. [CrossRef] [PubMed]

124. Davis, K.; Drey, N.; Gould, D. What are scoping studies? A review of the nursing literature. Int. J. Nurs. Stud. 2009, 46, 1386-1400. [CrossRef]

125. Arksey, H.; O'Malley, L. Scoping studies: Towards a methodological framework. Int. J. Soc. Res. Methodol. 2005, 8, 19-32. [CrossRef]

126. Edling, S.; Simmie, G.M. Democracy and emancipation in teacher education: A summative content analysis of teacher educators' democratic assignment expressed in policies for Teacher Education in Sweden and Ireland between 2000-2010. Citizsh. Soc. Econ. Educ. 2018, 17, 20-34. [CrossRef]

127. Braun, V.; Clarke, V. Successful Qualitative Research: A Practical Guide for Beginners; SAGE: New York, NY, USA, 2013.

128. Clarke, V.; Braun, V. Thematic Analysis. In Encyclopedia of Critical Psychology; Springer Science and Business Media LLC: Berlin/Heidelberg, Germany, 2014; pp. 1947-1952.

129. Hsieh, H.-F.; Shannon, S.E. Three approaches to qualitative content analysis. Qual. Health Res. 2005, 15, 1277-1288. [CrossRef] [PubMed]

130. Baxter, P.; Jack, S. Qualitative case study methodology: Study design and implementation for novice researchers. Qual. Rep. 2008, $13,544-559$.

131. Lincoln, Y.S.; Guba, E.G. Naturalistic Inquiry; SAGE Publications: Beverly Hills, CA, USA, 1985.

132. Shenton, A.K. Strategies for ensuring trustworthiness in qualitative research projects. Educ. Inf. 2004, 22, 63-75. [CrossRef]

133. Tzanakou, C.; Pearce, R. Moderate feminism within or against the neoliberal university? The example of Athena SWAN. Gender Work. Organ. 2019, 26, 1191-1211. [CrossRef]

134. Schmidt, E.K.; Ovseiko, P.V.; Henderson, L.R.; Kiparoglou, V. Understanding the Athena SWAN award scheme for gender equality as a complex social intervention in a complex system: Analysis of Silver award action plans in a comparative European perspective. Heal. Res. Policy Syst. 2020, 18, 1-21. [CrossRef]

135. Dearo, J.; Bird, S.; Ryan, S.M. NSF ADVANCE and gender equity. Equal. Divers. Incl. Int. J. 2019, 38, 131-139. [CrossRef]

136. Dell, E.; Bailey, M.B. Connectivity at RIT—Developing \& delivering an effective professional development workshop series for women faculty in stem. In Proceedings of the ASEE Annual Conference and Exposition, New Orleans, LA, USA, 26 June-28 August 2016.

137. Hain, A.; Zaghi, A.E.; Taylor, C.L. Board 164: Promoting Neurodiversity in Engineering through Undergraduate Research Opportunities for Students with ADHD. In Proceedings of the 2018 ASEE Annual Conference \& Exposition, Salt Lake City, UT, USA, 23 June-27 July 2018.

138. Mahlangu, V.P. Rethinking student admission and access in higher education through the lens of capabilities approach. Int. J. Educ. Manag. 2020, 34, 175-185. [CrossRef]

139. McLean, P.; Heagney, M.; Gardner, K. Going Global: The implications for students with a disability. High. Educ. Res. Dev. 2003, 22, 217-228. [CrossRef] 
140. Stallings, D.; Iyer, S.K.; Hernandez, R. National Diversity Equity Workshop 2017: Focus on Underrepresented Minorities in Chemistry Faculties. In National Diversity Equity Workshops in Chemical Sciences (2011-2017); American Chemical Society: Washington, DC, USA, 2018; pp. 109-140. [CrossRef]

141. Thompson, K.; Clune, D.; Eckstein, L.; Valenta, A.; Delbert, T. Overcoming Obstacles: Healthcare Students ith Disabilities on Fieldwork. Am. J. Occup. Ther. 2020, 74, 7411505233. [CrossRef]

142. Variawa, C.; McCahan, S. Design of the Learning Environment for Inclusivity: A Review of the Literature. Available online: https: // peer.asee.org/design-of-the-learning-environment-for-inclusivity-a-review-of-the-literature.pdf (accessed on 20 April 2021).

143. Iyer, S.; Stallings, D.; Hernandez, R. National Diversity Equity Workshop 2011: Lowering Barriers for all Underrepresented Chemistry Professors. In Proceedings of the ACS Symposium Series; American Chemical Society (ACS): Washington, DC, USA, 2018; pp. 21-49. [CrossRef]

144. Hadjikakou, K.; Hartas, D. Higher education provision for students with disabilities in Cyprus. High. Educ. 2007, 55, 103-119. [CrossRef]

145. Crabtree, S.A.; Hemingway, A.; Sudbury, S.; Quinney, A.; Hutchings, M.; Esteves, L.; Thompson, S.; Jacey, H.; Diaz, A.; Bradley, P. Donning the 'Slow Professor': A Feminist Action Research Project. Radic. Teach. 2020, 116, 55-65. [CrossRef]

146. Elwick, A. Valuing diversity in universities: Institutional value statements and the reality of student intakes. J. High. Educ. Policy Manag. 2020, 42, 269-284. [CrossRef]

147. Brewster, S.; Duncan, N.; Emira, M.; Clifford, A. Personal sacrifice and corporate cultures: Career progression for disabled staff in higher education. Disabil. Soc. 2017, 32, 1027-1042. [CrossRef]

148. Myers, L.; Parker, V. A New Millennium for Disabled Students in Higher Education? In Equality Issues for the New Millennium; Routledge: London, UK, 2018; pp. 89-102. [CrossRef]

149. Alphin, H.C., Jr.; Chan, R.Y.; Lavine, J. The Future of Accessibility in International Higher Education; IGI Global: Hershey, PA, USA, 2017.

150. Lowrey, K.A.; Smith, S.J. Including Individuals with Disabilities in UDL Framework Implementation: Insights from Administrators. Inclusion 2018, 6, 127-142. [CrossRef]

151. Robinson, O.; Henner, J. Authentic Voices, Authentic Encounters: Cripping the University Through American Sign Language. Disabil. Stud. Q. 2018, 38. [CrossRef]

152. Soorenian, A. Disabled people's inclusion in education: A global perspective. Disabil. Soc. 2018, 33, 810-814. [CrossRef]

153. Ehir, T.H. Eliminating Ableism in Education. Harv. Educ. Rev. 2002, 72, 1-33. [CrossRef]

154. Kattari, S.K. Examining Ableism in Higher Education through Social Dominance Theory and Social Learning Theory. Altern. High. Educ. 2015, 40, 375-386. [CrossRef]

155. Moola, F.J. The Road to the Ivory Tower: The Learning Experiences of Students with Disabilities at the University of Manitoba. Qual. Res. Educ. 2015, 4, 45-70.

156. Kearney, A. The right to education: What is happening for disabled students in New Zealand? Disabil. Stud. Q. 2016, 36. [CrossRef]

157. University of British Columbia. Employment Equity Report 2010. Available online: https://equity.ubc.ca/files/2011/07/ employment_equity_report-2010.pdf (accessed on 20 April 2021).

158. Bowen, S.; Zwi, A.B. Pathways to "evidence-informed" policy and practice: A framework for action. PLoS Med. 2005, 2, e166. [CrossRef]

159. Head, B.W. Three Lenses of Evidence-Based Policy. Aust. J. Public Adm. 2008, 67, 1-11. [CrossRef]

160. Young, K.; Ashby, D.; Boaz, A.; Grayson, L. Social Science and the Evidence-based Policy Movement. Soc. Policy Soc. 2002, 1, 215-224. [CrossRef]

161. Duke, K.; Thom, B. The role of evidence and the expert in contemporary processes of governance: The case of opioid substitution treatment policy in England. Int. J. Drug Policy 2014, 25, 964-971. [CrossRef]

162. Marmot, M.G. Evidence based policy or policy based evidence?: Willingness to take action influences the view of the evidenceLook at alcohol. BMJ Br. Med J. 2004, 328, 906-907. [CrossRef]

163. Howlett, M. Policy analytical capacity and evidence-based policy-making: Lessons from Canada. Can. Public Adm. 2009, 52, 153-175. [CrossRef]

164. Jensen, E. The UNESCO Recommendation on Science and Scientific Researchers will Transform Working Conditions, Rights and Responsibilities of Researchers Globally. Available online: https://blogs.lse.ac.uk/impactofsocialsciences/2020/1 0/05/the-unesco-recommendation-on-science-and-scientific-researchers-will-transform-working-conditions-rights-andresponsibilities-of-researchers-globally/ (accessed on 20 April 2021).

165. Mohamed, T.; Beagan, B.L. 'Strange faces' in the academy: Experiences of racialized and Indigenous faculty in Canadian universities. Race Ethn. Educ. 2019, 22, 338-354. [CrossRef]

166. Hodkinson, A.; Ghajarieh, A.; Salami, A. An analysis of the cultural representation of disability in school textbooks in Iran and England. Int. J. Prim. Elem. Early Years Educ. 2016, 46, 27-36. [CrossRef]

167. Cheng, K.K.Y.; Beigi, A.B. Addressing students with disabilities in school textbooks. Disabil. Soc. 2011, 26, 239-242. [CrossRef]

168. Ruskus, J.; Poceviciene, R. What Lithuanian Pupils Learn about Disability: Analysis of Attitudes and Content of Textbooks. Available online: https:/ / eric.ed.gov/?id=ED493956 (accessed on 20 April 2021).

169. Vidal-Albelda, B.; Martínez-Bello, V.E. Representation of bodies with and without disabilities in secondary school physical education textbooks. Sport Soc. 2016, 20, 957-968. [CrossRef] 
170. Snyder, S.L.; Mitchell, D.T. Re-engaging the body: Disability studies and the resistance to embodiment. Public Cult. 2001, 13, 367-389. [CrossRef]

171. Harnett, A. Escaping the evil avenger and the supercrip: Images of disability in popular television. Irish Commun. Rev. 2000, $8,21-29$.

172. Myers Hardin, M.; Hardin, B. The 'Supercrip' in sport media: Wheelchair athletes discuss hegemony's disabled hero. Sociol. Sport Online 2004, 7. Available online: https:/ / www.scinapse.io/papers/127108235 (accessed on 1 May 2021).

173. Kama, A. Supercrips versus the pitiful handicapped: Reception of disabling images by disabled audience members. Commun. 2004, 29, 447-466. [CrossRef]

174. Brylla, C. Bypassing the Supercrip Trope in Documentary Representations of Blind Visual Artists. Disabil. Stud. Q. 2018, 38, 11. [CrossRef]

175. The University of British Columbia. Equity \& Inclusion Glossary of Terms. Available online: https:/ / equity.ubc.ca/resources / equity-inclusion-glossary-of-terms/ (accessed on 20 April 2021).

176. University of Calgary. University of Calgary Canada Research Chair Equity Diversity and Inclusion Action Plan Appendix G: Chair Holder Employment Equity Self-Identification Form. Available online: https://www.ucalgary.ca/live-uc-ucalgary-site/ sites/default/files/teams/243/ucalgary-crc-edi-action-plan-updated-20190927.pdf (accessed on 20 April 2021).

177. Griffith University Australia. Disability Action Plan 2018-2020 Inclusive Practice for Staff, Students and the Community. Available online: https://www.griffith.edu.au/_data/assets/pdf_file/0032/169880/disability-action-plan.pdf (accessed on 20 April 2021).

178. University of Leeds. Supporting Disabled Staff. Available online: https://equality.leeds.ac.uk/support-and-resources/disability2/supporting-disabled-staff/ (accessed on 20 April 2021).

179. Guest, D.E. Perspectives on the Study of Work-life Balance. Soc. Sci. Inf. 2002, 41, 255-279. [CrossRef]

180. Crompton, R.; Lyonette, C. Work-life 'balance'in Europe. Acta Sociol. 2006, 49, 379-393. [CrossRef]

181. Culpepper, D.; Lennartz, C.; O’Meara, K.; Kuvaeva, A. Who Gets to Have a Life? Agency in Work-Life Balance for Single Faculty. Equity Excel. Educ. 2020, 53, 531-550. [CrossRef]

182. University of Toronto Equity Diversity and Inclusion Office. Equity, Diversity and Inclusion Office. Available online: https: / / webcache.googleusercontent.com/search?q=cache:k0ulWSe29tMJ:https://www.utsc.utoronto.ca/edio/equitydiversity-inclusion $+\& \mathrm{~cd}=1 \& \mathrm{hl}=\mathrm{en} \& \mathrm{ct}=\mathrm{clnk} \& \mathrm{gl}=\mathrm{ca}$ (accessed on 20 April 2021).

183. University of Toronto. Equity, Diversity \& Inclusion. Available online: https://research.utoronto.ca/equity-diversity-inclusion/ equity-diversity-inclusion (accessed on 20 April 2021).

184. Wolbring, G. Teaching about ability expectation and its governance: The issue of STEM. In Education and New Technologies Perils and Promises for Learners; Sheehy, K., Holliman, A., Eds.; Routledge: London, UK, 2017; pp. 122-140.

185. Xiong, S. The Development of the Disability Microagressions Scale. Master's Thesis, University of Illinois at Chicago, Chicago, IL, USA, 2016. Available online: https://indigo.uic.edu/articles/thesis/The_Development_of_the_Disability_Microagressions_ Scale/10801469/files/19312724.pdf (accessed on 20 April 2021).

186. Dundon, K. An Exploration of Faculty with Disabilities in Social Work Programs. Master's Thesis, University of Arkansas, Fayetteville, Arkansas, 2014. Available online: https://www.researchgate.net/profile/Kelly_Dundon2/publication/342509269_ An_Exploration_of_Faculty_with_Disabilities_in_Social_Work_Programs/links/5ef80942299bf18816eddccf/An-Explorationof-Faculty-with-Disabilities-in-Social-Work-Programs.pdf (accessed on 20 April 2021).

187. Kattari, S.K. The Development and Validation of the Ableist Microaggression Scale. J. Soc. Serv. Res. 2018, 45, 400-417. [CrossRef]

188. Verkuyten, M.; Thijs, J.; Gharaei, N. Discrimination and academic (dis)engagement of ethnic-racial minority students: A social identity threat perspective. Soc. Psychol. Educ. 2019, 22, 267-290. [CrossRef]

189. Ching, D.; Agbayani, A. Student Affairs's Voice, Visibility, and Relevance in Higher Education Administration. J. Coll. Character 2019, 20, 191-200. [CrossRef]

190. Rosser, S.V.; Barnard, S.; Carnes, M.; Munir, F. Athena SWAN and ADVANCE: Effectiveness and lessons learned. Lancet 2019, 393, 604-608. [CrossRef]

191. Williams, J.B. College and University Administrators with Disabilities: Experiences in the Workplace. Ph.D. Thesis, Colorado State University, Fort Collins, CO, USA, 2010. Available online: https://mountainscholar.org/bitstream/handle/10217/45977/ Williams_colostate_0053A_10229.pdf?sequence=1 (accessed on 20 April 2021).

192. Evans, W. 'I am not a dyslexic person I'm a person with dyslexia': Identity constructions of dyslexia among students in nurse education. J. Adv. Nurs. 2013, 70, 360-372. [CrossRef]

193. Wolbring, G.; Mackay, R.; Rybchinski, T.; Noga, J. Disabled People and the Post-2015 Development Goal Agenda through a Disability Studies Lens. Sustainability 2013, 5, 4152-4182. [CrossRef]

194. Participants of the UN Department of Economic and Social Affairs (UNDESA) and UNICEF. Organized Online Consultation 8 March-5 April Disability Inclusive Development Agenda towards 2015 \& beyond. Available online: http:/ / www.un.org/en/ development/desa/news/social/disability-inclusive-development.html (accessed on 20 April 2021).

195. Participants of the Global Online Discussion on Science Technology and Innovation for SDGs. Global Online Discussion on Science, Technology and Innovation for SDGs. Available online: https: / / sustainabledevelopment.un.org / forum / ?forum=20 (accessed on 20 April 2021). 
196. Misawa, M. Cuts and bruises caused by arrows, sticks, and stones in academia: Theorizing three types of racist and homophobic bullying in adult and higher education. Adult Learn. 2015, 26, 6-13. [CrossRef]

197. Johnson, S., II. Between a Rock and a Hard Place. Fem. Psychol. 2009, 19, 186-189. [CrossRef]

198. Nielsen, E.-J.; Alderson, K.G. Lesbian and queer women professors disclosing in the classroom: An act of authenticity. Couns. Psychol. 2014, 42, 1084-1107. [CrossRef]

199. Branfman, J. "(Un) Covering” in the Classroom: Managing Stigma Beyond the Closet. Fem. Teach. 2015, 26, 72-82. [CrossRef]

200. Newbolt, S.C. Dis / Ableist Consumption: A Critical Thematic Analysis of Avowed and Ascribed Neuro-Identities in the Classroom. Ph.D. Thesis, University of Denver, Denver, DO, USA, 2020. Available online: https://search.proquest.com/openview/ea114c7 3f31c6b0fc3bd3df84abc6f1b/1?pq-origsite=gscholar\&cbl=18750\&diss=y (accessed on 20 April 2021).

201. Foote, M.Q.; Bartell, T.G. Pathways to equity in mathematics education: How life experiences impact researcher positionality. Educ. Stud. Math. 2011, 78, 45-68. [CrossRef]

202. Broom, A.; Kirby, E.; Kokanović, R.; Woodland, L.; Wyld, D.; de Souza, P.; Koh, E.-S.; Lwin, Z. Individualising difference, negotiating culture: Intersections of culture and care. Health Interdiscip. J. Soc. Study Health Illn. Med. 2020, 24, 552-571. [CrossRef]

203. Austermuehl, F. The normalization of exclusion through a Revival of whiteness in Donald Trump's 2016 election campaign discourse. Soc. Semiot. 2020, 30, 528-546. [CrossRef]

204. Siller, H.; Tauber, G.; Hochleitner, M. Does diversity go beyond sex and gender? Gender as social category of diversity training in health profession education-A scoping review. GMS J. Med. Educ. 2020, 37, Document 25. [CrossRef]

205. Hapeta, J.; Palmer, F.; Kuroda, Y.; Hermansson, G. A Kaupapa Māori, culturally progressive, narrative review of literature on sport, ethnicity and inclusion. Kōtuitui N. Z. J. Soc. Sci. Online 2019, 14, 209-229. [CrossRef]

206. Fairclough, N. Analysing Discourse: Textual Analysis for Social Research; Psychology Press: London, UK, 2003.

207. Bauer, M.; Gaskell, G. Qualitative Researching with Text, Image and Sound; SAGE Publications, Ltd.: New York, NY, USA, 2000.

208. Schröter, M.; Taylor, C. Exploring Silence and Absence in Discourse: Empirical Approaches; Springer: Berlin/Heidelberg, Germany, 2017.

209. Dijk, T.A.V. Discourse, Knowledge, Power and Politics: Towards Critical Epistemic Discourse Analysis. Available online: https://repositori.upf.edu/bitstream/handle/10230/20021/WORKING\%20PAPERS\%20TEUN\%20VAN\%20DIJK.pdf? sequence $=1 \&$ is Allowed $=y$ (accessed on 20 April 2021).

210. University of Toronto. Equity Offices. Available online: https://hrandequity.utoronto.ca/inclusion/equity-offices/ (accessed on 20 April 2021).

211. University of Toronto. Accessibility for Ontarians with Disabilities Act (AODA) Office Accessibility information for U of T: Accessibility for Ontarians with Disabilities Act Office. Available online: https://hrandequity.utoronto.ca/inclusion/accessibility / (accessed on 20 April 2021).

212. University of Toronto Anti-Racism and Cultural Diversity Office. Anti-Racism and Cultural Diversity Office. Available online: https: / / antiracism.utoronto.ca/ (accessed on 20 April 2021).

213. Anti-Racism and Cultural Diversity Office. Reflect. Restore. Action. Available online: https://antiracism.utoronto.ca/ reflect-restore-action/?fbclid=IwAR07cDHwZqYPkRIVUpQuM0hk5d7uLUbRHQvVvKljo_Z2chpArrHk_EL_a6U (accessed on 20 April 2021).

214. University of Toronto Sexual \& Gender Diversity Office. Available online: https://sgdo.utoronto.ca/about-the-office/missionvalues-vision/ (accessed on 20 April 2021).

215. Princeton University. University Policies Support Individuals with Disabilities, in Compliance with ADA. Available online: https:/ / www.princeton.edu/news/2016/12/19/university-policies-support-individuals-disabilities-compliance-ada (accessed on 20 April 2021).

216. Princeton University. Disability \& Accessibility. Available online: https://inclusive.princeton.edu/addressing-concerns/ disability-accessibility (accessed on 20 April 2021).

217. Program of Community Rehabilitation and Disability Studies University of Calgary. About Us. Available online: https: / / cumming.ucalgary.ca/bcr/about (accessed on 20 April 2021).

218. CRC Equity Plan Advisory Committee Simon Fraser University. Canada Research Chairs Program: Equity, Diversity and Inclusion Action Plan. Available online: https:/ / www.sfu.ca/research/sites/default/files/2019-10/SFU\%20CRC\%20Equity\% 2C\%20Diversity\%2C\%20and\%20Inclusion\%20Action\%20Plan.pdf (accessed on 20 April 2021).

219. University of Toronto. University of Toronto crc Chairholder Self-Identification Form. Available online: https://research.utoronto. $\mathrm{ca} /$ media/147/download (accessed on 20 April 2021).

220. University of Ottawa. Awareness: Did You Know? Available online: https://www.uottawa.ca/wellness/about/awareness (accessed on 20 April 2021).

221. Government of Canada. Canada Research Chairs Program Statistics. Available online: https://www.chairs-chaires.gc.ca/about_ us-a_notre_sujet/statistics-statistiques-eng.aspx\#a3 (accessed on 20 April 2021).

222. Griffith University Australia. Equity, Diversity and Inclusion Plan 2018-2019. Available online: https://www.griffith.edu.au/_ data/assets/pdf_file/0028/533278/FINAL_Equity-Diversity-and-Inclusion-Plan-2018-2019.pdf (accessed on 20 April 2021).

223. Griffith University Australia. Creating a Future for all STRATEGIC PLAN 2020-2025. Available online: https:/ /www.griffith.edu. au/_data/assets/pdf_file/0037/932698/Strategic-Plan-2020-2025.pdf (accessed on 20 April 2021). 
224. Riddell, S.; Weedon, E. Disabled students in higher education: Discourses of disability and the negotiation of identity. Int. J. Educ. Res. 2014, 63, 38-46. [CrossRef]

225. Merchant, W.; Read, S.; D’Evelyn, S.; Miles, C.; Williams, V. The insider view: Tackling disabling practices in higher education institutions. High. Educ. 2019, 80, 273-287. [CrossRef]

226. De Bie, A. Respectfully distrusting 'Students as Partners' practice in higher education: Applying a Mad politics of partnership. Teach. High. Educ. 2020, 1-21. [CrossRef]

227. Congress Advisory Committee on Equity Diversity Inclusion and Decolonization (AC-EDID) Canada. Igniting Change: Final Report and Recommendations. Available online: http:/ / www.ideas-idees.ca/about/CAC-EDID-report (accessed on 20 April 2021).

228. Diep, L. Anticipatory Governance, Anticipatory Advocacy, Knowledge Brokering, and the State of Disabled People's Rights Advocacy in Canada: Perspectives of Two Canadian Cross-Disability Rights Organizations. Master's Thesis, University of Calgary, Calgary, AB, Canada, 2017. Available online: https://prism.ucalgary.ca/bitstream/handle/11023/4051/ucalgary_2017 _diep_lucy.pdf?sequence=3\&isAllowed=y (accessed on 20 April 2021).

229. World Bank; World Health Organization. World Report on Disability. Available online: https://www.who.int/disabilities/ world_report/2011/report.pdf (accessed on 20 April 2021).

230. Roufs, K.S. PhD Thesis Members of Faculty with Hearing Impairments in Academia: What Are Their Needs? Available online: https:/ / conservancy.umn.edu/bitstream/handle/11299/119351/Roufs_umn_0130E_12382.pdf?sequence=1\&isAllowed= y (accessed on 20 April 2021).

231. Weiss, L.A. Understanding Faculty Members Living with Disabilities in Higher Education. Ph.D. Thesis, Ball State University, Muncie, Indiana, 2016. Available online: https:/ / cardinalscholar.bsu.edu/bitstream/handle/123456789/200563/WeissL_2016-1 BODY.pdf?sequence=1\&isAllowed=y (accessed on 20 April 2021).

232. Anderson, R.C. Bodies of Knowledge: Faculty Members with Disabilities in Higher Education. Ph.D. Thesis, The University of Alabama, Tuscaloosa, AL, USA, 2006. Available online: https://search.proquest.com/openview/d6a21367ec2e95270cb4378064

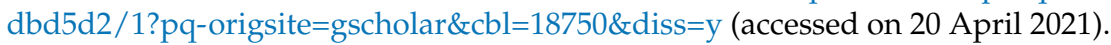

233. Dolan, V.L.B. Faculty Narratives of Disability in Academic Work. Ph.D. Thesis, University of Toronto, Toronto, ON, Canada, 2018. Available online: https://tspace.library.utoronto.ca/bitstream/1807/89869/1/Dolan_Vera_L_201806_PhD_thesis.pdf (accessed on 20 April 2021).

234. Sanders, R. Thesis: Qualitative Analysis of Diversity, Equity, and Inclusion-Related Content on Websites of High School Districts in Illinois. Available online: https://search.proquest.com/openview/30a4a807b5592a46f066fdda2a01bb52/1?pq-origsite= gscholar\&cbl=18750\&diss=y (accessed on 20 April 2021).

235. Wolbring, G.; Deloria, R.; Lillywhite, A.; Villamil, V. Ability Expectation and Ableism Peace. Peace Rev. 2019, 31, 449-458. [CrossRef]

236. Burke, M.A.; Eichler, M. Building an Integrative Analytical System for Recognising and Eliminating inEquities. (BIAS FREE Framework). Available online: https:/ / ethz.ch/content/specialinterest/gess/cis/center-for-securities-studies/en/services/ digital-library/publications/publication.html/128225 (accessed on 20 April 2021).

237. Eichler, M.; Burke, M.A. The BIAS FREE Framework. Can. J. Public Health 2006, 97, 63-68. [CrossRef] [PubMed] 